Article

\title{
Application and Validation of a Municipal Administrative Area Spatial Zoning Model in Village-Town System Planning
}

\author{
Yujing Zhao ${ }^{1,2}$, Hong Leng ${ }^{1,2, *}$, Pingjun Sun ${ }^{3, *}$ and Qing Yuan ${ }^{1,2}$ \\ 1 School of Architecture, Harbin Institute of Technology, 66 West Dazhi Street, Nangang District, \\ Harbin 150001, China; zhaoyujingli@126.com (Y.Z.); hityuanqing@hit.edu.cn (Q.Y.) \\ 2 Key Laboratory of Cold Region Urban and Rural Human Settlement Environment Science and Technology, \\ Ministry of Industry and Information Technology, 66 West Dazhi Street, Nangang District, \\ Harbin 150001, China \\ 3 School of Geography Sciences, Southwest University, NO.2 Rd Tiansheng, Beibei District, \\ Chongqing 400715, China \\ * Correspondence: hitlaura@126.com (H.L.); sunpj031@163.com (P.S.)
}

Received: 23 January 2019; Accepted: 20 March 2019; Published: 28 March 2019

\begin{abstract}
The overall planning of urban and rural areas is the focus of municipal administrative area (MAA) planning in the process of economic globalization, and village-town system planning is the key to the overall planning of urban and rural areas. Based on the theory of spatial equilibrium and economic logic, an objective municipal administrative area spatial zoning model (M-MSZ) was constructed in our previous study. The M-MSZ model can provide guidance in the planning of a village-town system. This paper takes a city in the south of Heilongjiang Province in China as an example and compares the M-MSZ model with six traditional MAA spatial zoning models (the urban growth boundary model, land use planning model, spatial governance zoning model, major MAA location, layout and planning model, development timing-order and zoning model, and scale and function zoning model) to verify the value and superiority of the M-MSZ model in the planning of a village-town system. The consistency Kappa values were 78.2\%, 83.3\%, 82.3\%, 79.8\%, 75.7\%, and $83.9 \%$, respectively, which means that the M-MSZ model was highly consistent with those comparison models. Meanwhile, the regression coefficient $R^{2}$ is higher than that of the traditional spatial zoning models, which means that the objectivity of the M-MSZ model is higher than that of traditional models. The superiority of the M-MSZ model over the traditional MAA spatial zoning model lies not only in its capacity to grasp the core content of village-town system planning, but also in its capacity to unify the decentralized urban system planning models that are used for village-town system planning, while realizing the objectivity of a weight assignment. Its unified model structure, objective integrated model system, and high accuracy make the M-MSZ model capable of solving the key problems associated with village-town system planning, with many advantages, such as easy operation, high efficiency, good inheritance, low cost, and greater objectivity, detail, and accuracy. In addition, it can provide a reference for the development model of a MAA village-town system.
\end{abstract}

Keywords: major functional areas; municipalities; spatial zoning model (administrative area spatial zoning model); village-town system planning; Heilongjiang

\section{Introduction}

Economic globalization requires a high degree of integration of the urban and rural spatial economy, society, and environment, and urban and rural co-ordination, but the development of villages and towns in various countries is fraught with many problems, such as the phenomenon 
of idle land in villages and towns [1-8], the abandonment and extensive management of land, less comprehensive utilization [9-11], the scattered distribution of land use [12,13], and the lack of governance of agricultural production and pollution in villages and towns [13-16]. These problems hinder the promotion of rural productivity, aggravate the contradiction between urban and rural areas, and delay the process of urban-rural integration. With the aggravation of rural problems and the widening gap between urban and rural areas, the concept of urban-rural coordination has become a worldwide topic [17-20]. Municipal administrative area (MAA) spatial zoning is a key step to the coordination of urban and rural planning, and it is also a key link to guiding the layout of urban and rural industrial development, land zoning, functional positioning, and facilities allocation [21,22]. At present, the MAA spatial zoning used to solve the planning problem of the village-town system mostly draws lessons from the city system planning model $[17,23]$. They are used to eliminate some key problems in the village-town system, and many kinds of relevant models are needed for reference. The difference between different construction systems leads to different land attribute requirements or unclear land attributes in the same area of village-town system planning [17]. In order to solve the problems associated with the planning of a village-town system, an efficient, convenient, rational, scientific, and unified model of MAA spatial zoning is needed to perfect the planning, updating, and reform of the village-town system. The only way to break up the dual structure of urban and rural areas is to achieve urban and rural co-ordination.

Village-town system planning has five major aspects. First, various kinds of forecasting, including at the village-town scale, and the functional orientation of MAA villages and towns. Secondly, MAA land use zoning and layout, including the zoning of the urban growth boundary, land use planning, and space governance zoning. Thirdly, the location, layout and planning of the major regions in MAA, including key village-town planning, industrial land layout, and the location and layout of village relocation and consolidation. Fourthly, MAA development timing-order. Fifthly, other special plans, including comprehensive transportation, facilities, tourism, disaster prevention, historical and cultural protection, etc. [17]. When relevant, various kinds of forecasting, MAA land use zoning and layout, the location, layout and planning of the major regions in MAA, development timing-order, and other special plans form the basis of other types of special planning and the key content of village-town system planning [23]. This paper takes village-town system planning (except special planning) as the application background for the study of MAA spatial zoning.

At present, the MAA spatial zoning models used to solve the key problems in the planning of a village-town system can be roughly divided into six categories, according to their different functions: the scale and function zoning model, urban growth boundary model (UGB model), land use planning model, spatial governance zoning model, location of major regions, layout and planning model (including key village-town planning, industrial land layout, village relocation and consolidation), and development timing-order and zoning model. The principles and methods of these models are mostly derived from city system planning [17].

The scale and function zoning model is an early model that is used to study the spatial scale and function of villages and towns. It divides the scale and function of villages and towns from bottom to top based on the conditions, population, and land quantity of villages and towns by means of simulation prediction or goal optimization technology. There are three representative types for this kind of model. Firstly, is the mathematical analysis and prediction models, such as the rank-size rule, Pareto distribution model, minimum demand model, regression analysis and prediction model, grey prediction model, Markov prediction model, neural network prediction model, linear programming model, spatial input-output model, etc. The other two are the System Dynamics Model and Biological Intelligence Algorithms Model. People [24-34] also used the mathematical analysis and prediction model, system dynamics model, and bio-intelligent algorithm model to study the size and function zoning of villages and towns. From a comparison of models with various scales and functions, it was found that the mathematical analysis and prediction model is a simple and effective way to divide the size and function of villages and towns. It considers less driving factors of land use change and is easy 
to determine. Correspondingly, the system dynamics model and bio-intelligent algorithm model are good at dealing with complex non-linear multiple feedback problems and can simulate all aspects of land use, such as society, economy, and environment.

After globalization, due to the game of development and protection, the contradiction between living space, agricultural production space, and ecological space has become increasingly intensified [35]. Secondly, the UGB model has become the main stream of research. This model focuses on the existing living space, population distribution, and scale of villages and towns. Then, it uses different models to simulate the development boundary of the living space of villages and towns during different periods by the subjective weight setting method. This mainly includes the CLUE-S analysis system, Cellular Automata (CA), and SLEUTH model. Researchers use the above UGB models to carry out empirical research on the delimitation of living space in villages and towns [35-42]. From these empirical studies, we found that the CLUE-S analysis system needs less data. The parameters are sensitive and widely applicable. Correspondingly, the cellular automata model and SLEUTH model can reflect the evolution process of village space, which needs more comprehensive data. This model can more comprehensively reflect the spatial function changes of villages and towns during different periods.

The urban growth boundary is closely related to the size of villages and towns, so the land use planning model, combining the scale and function zoning with the urban growth boundary, was developed. This model uses the method of subjective setting weight to simulate the land function of villages and towns during different periods, according to the causal relationship between the space of villages and towns or the relationship between the factors affecting the land use of villages and towns. This mainly includes the CA-Markov prediction model, CA-neural network prediction model, SLEUTH-Markov prediction model, and SLEUTH-neural network prediction model. It is common to use the UGB model, coupled with the mathematical analysis and prediction model, to complete the land function zoning of villages and towns. For example, Kamusoko and others used the CA and Markov prediction model or neural network prediction model to complete land use planning in Bindura and other places $[43,44]$. Due to the complexity of the model, its function of land use planning has the remarkable characteristics of the composite model, that is, the model has both the characteristics of the selective UGB model and that of the scale and function zoning model.

Thirdly, with the confusion of the MAA spatial function, Spatial Governance Zoning has been proposed by scholars as a planning strategy for limitation and regulation. Based on the main influencing factors of spatial governance zoning, the spatial governance zoning model divides the major functions of the village-town system using the method of subjective setting weight, which provides the basis for the functional orientation of the village and the direction of future development. It mainly includes the major function zoning model [45], dominant priority zoning model [46], and intensive land use zoning model, integrated with land-use zoning [47]. Among them, the most representative one is the principal function zoning model, which has been widely used in the spatial zoning of village-town system planning in long-term research and has achieved good results. Fan, Jie and others used the principal function zoning model to study the prohibited, limited, and development zones of village-town system planning in large-scale regions of China [48-50].

With the in-depth study of village-town systems, researchers have been moving from macro-land-use zoning to the location and layout of meso-land-use and the location of major regions, and layout and planning models have emerged in great numbers. Based on the gravity principle or spatial segmentation theory, this model regards factors, such as population and job distribution, as attraction or spatial segmentation factors. Usually, the method of subjective setting weight is used to simulate the spatial attraction range of villages and towns to determine the required location. It mainly includes the gravity model [51], breaking point model [52], and potential model [53]. Among them, the gravity model and fracture point model are mostly used in the study of the location of village-town systems. Tian, Yasi et al. used the gravity model and fracture point model to study site selection and 
the key village-town planning of village-town systems, respectively. Their application results can provide a reference for the spatial layout and optimization of village-town system planning [51,54-59].

With the continuous deepening of the spatial planning of village-town systems, timing-order planning has also been put forward. Exploring the development timing-order of village-town systems has become a new research hotspot. Based on the selection of influencing factors for the spatial development of villages and towns, the timing-order and zoning model make reasonable judgments about the spatial development of villages and towns using the method of subjective setting weight. The models include the matter-element-based model [60] and development suitability model [61], based on the subjective weighting method. Cengiz, Tuelay et al. use the development suitability model, based on the subjective setting weight method, to evaluate the suitability of the spatial development of village-town systems and to study the development timing-order. The application results of this model can provide a spatial layout basis for the planning of a village-town system [61-63].

Overall, the existing six types of MAA spatial zoning models used to solve the problem of village-town system planning have their own advantages according to their respective functions, but there are some shortcomings in the application of a village-town system. First, the existing village-town system planning uses different city system planning models to solve the targeted problems. The contradictions and complexities, brought about by the application of different models in the same region, cannot be controlled. Generally, the UGB model is used to solve the problem of the living space boundary of villages and towns [35], the spatial governance zoning model is used to solve the problem of agricultural space and ecological space zoning in villages and towns [45], and the development timing-order and zoning model is used to solve the problem of the development timing-order of villages and towns. [60] Different assignment and weights of the reference factors, parameters, and factors lead to space-time contradictions in the planning of village-town systems. For example, there are different attribution spaces for different planning cases in the same region. Sometimes, the simulation results of the Spatial Governance Zoning model in the same region are priority development areas, but the simulation results of the development suitability zoning model are unsuitable development areas. Secondly, the scale and function zoning model is a bottom-up way to determine the level of each village in the MAA after comparing itself to other villages. However, the planning of village-town systems is often determined by a top-to-bottom method. Therefore, there may be inconsistency or inadaptability in the combination of the function, scale of each village and the planning of the village-town system. Thirdly, the UGB model, land use planning model, spatial governance zoning model, location selection of major regions, layout and planning model, and development timing-order and zoning model mainly use the subjective method of setting weights to solve the different functions of the village-town system. This subjective judgment is not objective and impartial. In addition, the economic level of villages and towns is lower than that of cities, so the concept of villagers lags behind, and the planning and management of the village-town system lags behind as well. What is worse, the professional quality of the relevant talents and the ability to apply complex and diverse models are relatively lacking [64]. Therefore, it is very difficult to apply various city system models to solve the problems associated with a village-town system.

In our previous study, we built a quantitative and easily operated model (the municipal administrative area spatial zoning model, M-MSZ model) for MAA spatial zoning, based on the existing spatial equilibrium model for regional development [65]. The obtained model was optimized with combination of the neural network and expert public decision analysis methods [66-68], and it is compared with the existing spatial zoning models (including the urban structure zoning model, UGB model and major function-oriented zoning model) using the same factors. Moreover, three representative cities in China were modeled empirically using this model, and the results were compared with those obtained using the existing models. We investigated the image consistency of this model to the three existing models, and the Kappa values (judgment method of image consistency) were $85.9 \%, 88.2 \%$, and $85.2 \%$, respectively, with an average of $86.4 \%$ [65]. This shows that the model can reduce the data limitation and expand the scope of application, while ensuring the accuracy of 
the model analysis results. Meanwhile, the ecological-agricultural production-living spaces (EPLs) zoning is clearer, which makes the spatial plan coordination more efficient and scientific. It is used to solve the spatial planning problems of MAA, which are associated with a village-town system in special zoning. In order to verify the application value of the M-MSZ model in the planning of a village-town system, this paper uses the M-MSZ model to further simulate the application in the spatial planning of a village-town system. This paper applies the M-MSZ model to the key problems in the planning of a village-town system based on the idea of the comprehensive development of villages and towns and the protection of agriculture and ecology. A city in Southern Heilongjiang was taken as an example. The results show that the M-MSZ model has advantages in solving such problems as the delimitation of the urban growth boundary, land use planning, spatial governance zoning, key village-town planning, industrial land layout, location and layout of village relocation and consolidation, MAA development timing-order, village-town scale, and function location prediction of villages and towns. This model is more efficient, objective, and unified than the six traditional models of MAA spatial zoning (the UGB model, land use planning model, spatial governance zoning model, location selection of major regions, layout and planning model, development timing-order and zoning model, and scale and function zoning model). At the same time, the M-MSZ model not only can effectively guide the development model, the intensive use of land, and the ecological protection of villages and towns, but can also guide the relevant planning of the city system and provide reference ideas for the overall planning of urban and rural areas.

\section{Research Method, Research Area, and Data Processing}

Based on the current situation of village-town system planning and the practical problems existing in villages and towns, this paper proceeds with the status quo of the study area, model, and data processing of the M-MSZ model.

\subsection{Research Method}

In our previous studies, based on the theory of spatial equilibrium and for the purpose of studying the suitability of urban spatial development, the M-MSZ model is constructed by using economic logic derivation and deriving model factor relations objectively. The model is shown as Formula (1). The model factor was selected by referring domestic and foreign relevant research and investigating the main body of the urban area and relevant expert opinions. In this model, the main functional areas are divided into limited conditions to refine the zoning problem of EPLs (Life, Production, and Ecological Space) [65] in MAA that are suitable for development, agriculture, and ecological protection, respectively. This model is used to solve the spatial zoning problems of urban area, villages, and village-town systems of MAA. The model is used to simulate and analyze the urban spatial zoning and the results are compared with that of the three existing regionalization models (urban structure model, UGB delimitation model, and functional zoning model). The average Kappa value is $81.3 \%$, which verifies the correctness of the model. The factors of the model include available land resources, population aggregation, economic development level, location advantages, transportation advantages, number of undeveloped zones and those zones that have not been built or adjusted by the state and government, topography and topography, natural disasters, available water resources, environmental capacity, and ecosystem vulnerability. Among them, the objective factor with a high contribution rate to the M-MSZ model, such as the economic development level, population concentration, location advantage, traffic advantage, the amount of available land resources, and the objectification of the factor weight of the number of undeveloped zones and those zones that have not been built or adjusted by the state and government, gives the M-MSZ model greater advantages than the reference model [62]. In order to reflect the superiority and practical value of the M-MSZ model of urban spatial zoning based on the background of main functional areas, this paper uses M-MSZ model to further apply in the planning of village-town system. 


$$
D(r)=\left(\frac{L_{1}^{2} N_{1} \lambda t Y e^{\left(\lambda t\left|r-y-r_{0}\right|\right)}}{e^{\lambda t r}-1}\right)\left(p^{x_{1}}\left(y+\mathrm{r}_{0}\right)^{x_{2}} J^{x_{3}}\right)^{(1-\mu)}\left(\frac{\sigma-1}{\sigma}\right)^{\mu} M_{1}(r)^{\left|\frac{\mu}{1-\sigma}\right|}[65]
$$

2.2. Present Situation of the Research Area, Contradictions of Various Kinds of Planning, and Explanation of Data Sources

The study area is located in the south of Heilongjiang Province in China, and the northwest is connected with Harbin, the capital of Heilongjiang Province. The location of the research area is shown as Figure 1. The main landform types in the territory are low hills and hills, supplemented by plains and valleys. The elevation is generally between 112 and 826 meters. The distribution of water resources is uneven, and the natural environment varies greatly. In 2017, the urban population accounted for about $1 / 2$ of the total population; the urban area accounted for more than $1 / 5$ of the total regional area; and the secondary and tertiary industry GDP accounted for about $85 \%$ of the total GDP (Data resource: Statistical Yearbook 2017 of Heilongjiang Province).

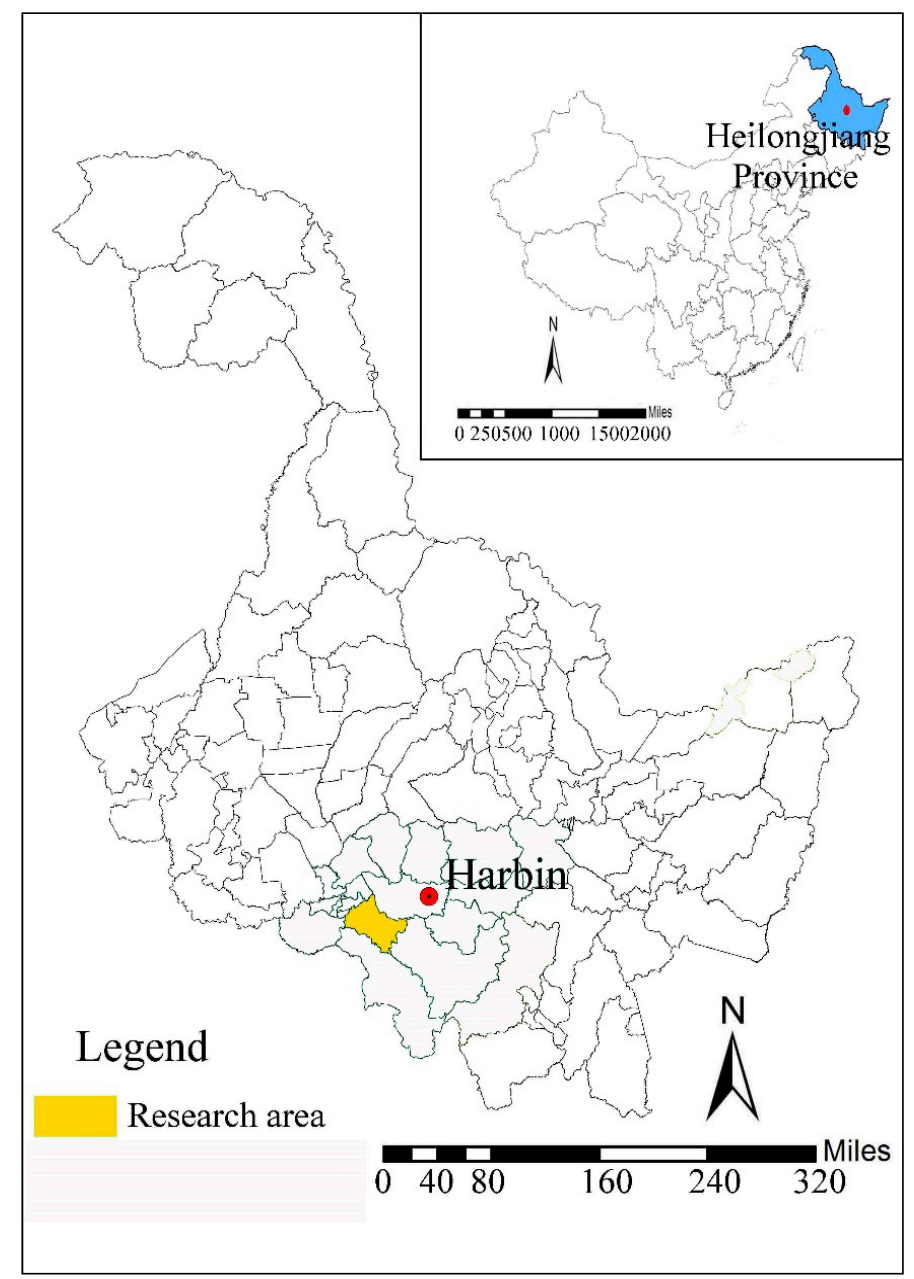

Figure 1. Location of the research area.

Comparing urban and rural planning (2011-2030), land use planning (2013-2030), and ecological environment protection planning (2014-2030), it is found that there are planning contradictions over nearly $312 \mathrm{~km}^{2}$ of land, accounting for about $12.7 \%$ of the total area of the city. Among them, the area of contradiction between urban and rural planning and land use planning is $73.3 \mathrm{~km}^{2}$, mainly existing in the general farmland for agricultural production, located in the suburbs. At the same time, the area of contradiction between urban and rural planning and ecological environmental 
protection planning is $32.4 \mathrm{~km}^{2}$, mainly concentrated in the construction land, located in the suburbs. Moreover, the area of contradiction between land use planning and ecological environmental protection planning is $206.2 \mathrm{~km}^{2}$ and mainly includes the contradiction between garden land, general farmland for agricultural production, grassland, and woodland. Vector data in this paper are mainly based on the data of the 2013 Geographic National Conditions Census, CGCS 2000 coordinate system, 1985 National elevation benchmark, and the Gauss-Kruger 6 zonal projection data.

\subsection{Data Processing}

In order to test the accuracy of the model factor threshold and partial factor weight assignment method, this paper employs the factor weight assignment method used in our previous research, namely, a combination of the neural network and expert public decision analysis methods $[67,68]$. By investigating the actual situation of the cities of Heilongjiang, 11,534 valid questionnaires were applied to determine 11 impacts and the threshold setting of the impacts. The threshold of each factor is set as Table 1. The weights allocation and threshold assignment of expert and public opinions are shown in the Supplementary Materials.

Table 1. Factors assignment of the municipal administrative area spatial zoning model (M-MSZ) Model.

\begin{tabular}{|c|c|c|c|c|c|c|}
\hline \multirow{2}{*}{\multicolumn{2}{|c|}{ Factors of the M-MSZ Model }} & \multicolumn{5}{|c|}{ Level } \\
\hline & & 1 & 2 & 3 & 4 & 5 \\
\hline \multirow{2}{*}{$\begin{array}{l}\text { Population } \\
\text { Quantity }\end{array}$} & Growth Rate of Population & $>10 \%$ & $3 \% 0-10 \%$ & $-3 \% 0-3 \%$ & $-10 \% 0--3 \%$ & $<-10 \%$ \\
\hline & D Value & 1.8 & 1.6 & 1.4 & 1.2 & 0.8 \\
\hline \multirow{2}{*}{$\begin{array}{l}\text { Economic } \\
\text { Situation }\end{array}$} & Economic Growth Intensity & $>20 \%$ & $15 \%-20 \%$ & $10 \%-15 \%$ & $0 \%-10 \%$ & $<0 \%$ \\
\hline & K Value & 1.5 & 1.4 & 1.3 & 1.2 & 1 \\
\hline \multirow{4}{*}{$\begin{array}{l}\text { Transport } \\
\text { Superiority } \\
\text { Degree }\end{array}$} & $\begin{array}{c}\text { Railway Stations, } \\
\text { Expressways and Main } \\
\text { Roads at All Levels }(\mathrm{Km})\end{array}$ & $<2$ & $2-3$ & $3-4$ & $4-6$ & $>6$ \\
\hline & Arterial Airport (Km) & $<30$ & $30-60$ & $60-90$ & $90-120$ & $>120$ \\
\hline & $\begin{array}{l}\text { Regional Airports and } \\
\text { Ports }(\mathrm{Km})\end{array}$ & $<20$ & $20-30$ & $30-40$ & $40-60$ & $>60$ \\
\hline & Superimposed Fraction & 15 & $12-14$ & $9-11$ & $6-8$ & $3-5$ \\
\hline \multirow{3}{*}{$\begin{array}{l}\text { Location } \\
\text { Advantage }\end{array}$} & Inner Location Advantage & \multicolumn{5}{|c|}{ Divide into Five Grades with Equidistant Way } \\
\hline & $\begin{array}{l}\text { Exterior Location } \\
\text { Advantage }\end{array}$ & $0-30$ & $30-60$ & $60-90$ & $90-120$ & $>120$ \\
\hline & Superimposed Fraction & 10 & $8-9$ & $6-7$ & $4-5$ & $2-3$ \\
\hline \multirow{3}{*}{$\begin{array}{l}\text { Topographic and } \\
\text { Terrain }\end{array}$} & Height (M) & $0-210$ & $200-500$ & $500-1000$ & $1000-1350$ & $>1350$ \\
\hline & Slope $\left({ }^{\circ}\right)$ & $\leq 3$ & $3-10$ & $10-15$ & $15-50$ & $>50$ \\
\hline & Superimposed Fraction & 10 & $8-9$ & $6-7$ & $4-5$ & $2-3$ \\
\hline $\begin{array}{c}\text { Utilization of } \\
\text { Land Resources }\end{array}$ & Area $\left(\mathrm{Km}^{2}\right)$ & $>320$ & $200-320$ & $150-200$ & $100-150$ & $<100$ \\
\hline $\begin{array}{c}\text { Utilization of } \\
\text { Water Resources }\end{array}$ & $\begin{array}{l}\text { Utilization of Water } \\
\text { Resources Per Capita } \\
\text { (M3/Capita) }\end{array}$ & $2000-3200$ & $1500-2000$ & $1000-1500$ & $500-1000$ & $0-500$ \\
\hline \multicolumn{2}{|r|}{ Number * } & $\geq 4$ & 3 & 2 & 1 & 0 \\
\hline Natural Disaster & $\begin{array}{c}\text { Risk of Floods, Droughts, } \\
\text { Earthquakes and Forest } \\
\text { Fires }\end{array}$ & No & Common & Great & Significant & Outsize \\
\hline $\begin{array}{l}\text { Environmental } \\
\text { Capacity }\end{array}$ & $\begin{array}{l}\text { ai: Capacity Indicator for } \\
\text { Individual Environmental } \\
\text { Capacity) }\end{array}$ & $\mathrm{Ai} \leq 0$ & $0<\mathrm{ai}<1$ & $1<$ ai $<1.5$ & $1.5<$ ai $<2$ & $\mathrm{ai} \geq 2$ \\
\hline $\begin{array}{l}\text { Ecosystem } \\
\text { Vulnerability }\end{array}$ & $\begin{array}{l}\text { Evaluation Results of } \\
\text { Ecological Vulnerability }\end{array}$ & $0-0.2$ & $0.2-0.4$ & $0.4-0.6$ & $0.6-0.8$ & $0.8-1.0$ \\
\hline
\end{tabular}

Note: * Number of Development Zones That is Not Built Up, Or Development Zones Undeveloped After Adjusted by the State or Government. 


\section{Result}

\subsection{Model Validation and Comparative Application}

From the point of view of the current use of the existing MAA spatial zoning model, the practicability of the single model has been validated for a long time. However, the lack of coordination between the models leads to the problem of the time-space connection of land attribution in MAA village-town system planning. Much subjective speculation in the construction of the MAA spatial zoning model makes the M-MSZ model violate objectivity and fairness in solving the problems associated with the village-town system. In order to investigate the superiority of the M-MSZ model in solving the key problems in village-town system planning, such as zoning and the layout of village-town land, the location, layout and planning of major regions, development timing-order, and scale and function prediction, the simulation results of the M-MSZ model were compared with the comparison model and government behavior results. Briefly, the boundary delimitation of spatial growth, land use planning, space governance zoning, key village-town planning, industrial land layout, location and layout of village relocation and consolidation, development timing-order, and scale and function positioning in the village-town system were studied. The results are as follows.

\subsubsection{Demarcation of Urban Growth Boundary}

As we know, the urban growth boundary is defined in various different ways. In this paper, we predict that the UGB will reflect the rigid boundary of the spatial growth of villages and towns in the study area more comprehensively. Therefore, the CA-based urban growth boundary delimitation model (construction land boundary during a certain period), proposed by Longying et al. [38], is adopted, which has been widely used in MAA urban growth boundary determination [69-72]. First, CA and GIS are used to select a grid with a size of $100 \mathrm{~m} \times 100 \mathrm{~m}$ for calculation. Then, the grid results are vectorized, and the low compactness and small area (under 1 hectare) of land, which are not suitable for urban and rural construction on a certain scale, are deleted. After that, we select the factors of the contrast model through the evaluation system. Then, the factor weights were equally divided according to expert opinions (all the following factors and weight settings of the applied model are the same as those of the M-MSZ model). UGB is delimited on the basis of an average annual population growth rate of $5 \%$ and construction land per capita of $120 \mathrm{~m}^{2}$. Lastly, based on the current land use data of the study area in 2016, we calculated the per capita construction land and population growth to determine when the region will reach the rigid boundary of living space in the next 50 years. The living space boundary of the village-town system in the next 50 years was obtained, as shown in Figure 2a. Compared with the urban growth boundary, the consistency kappa value is $78.2 \%$, and the consistency test value is higher. The main reason for the improvement is that the introduction of the limitation of the major function area refines the spatial classification, which provides the M-MSZ model with the limitation that the major function delineates the urban growth boundary. Due to the limiting role of the major functional areas, the M-MSZ model has a higher accuracy in delineating urban transitional zones (except the existing built-up zones and control zones), and it is more convincing in guiding the spatial zoning of the transitional zones. We believe that removing the limitation of the major functional zones may lead to an inconsistency between the transitional zone of zoning and the main function, which shows the necessity of limiting the major function area. At the same time, the objective factor weight of the M-MSZ model, especially for those factors with a high contribution rate to the M-MSZ model, such as the economic development level, population concentration, location advantage, traffic advantage, the amount of available land resources, and the objectification of the factor weight of the number of undeveloped zones and those zones that have not been built or adjusted by the state and government, gives the M-MSZ model greater advantages than the reference model. The objectivity of the M-MSZ model and the contrasting UGB model are analyzed by multiple non-linear regression analysis and linear regression analysis, respectively. It is found that the $\mathrm{R}^{2}$ value of the M-MSZ model is 0.77 , and the $\mathrm{R}^{2}$ value of the contrast model is 0.75 , which proves that the M-MSZ model is more 
objective than the contrasting model in the actual fitting process. In addition, the UGB delimitation model can only divide living space, which is less practical than the M-MSZ model in the application of EPLs. This is also the outstanding characteristic of the M-MSZ model in coordinating urban and rural spatial planning. Compared with the government behavior (Figure 2a,b), the kappa value is $83.8 \%$, and the consistency is high. This proves the accuracy of the M-MSZ model. According to the results, we suggest that, in the next 50 years, urban construction land should be reserved, future land docking should be prepared, and construction land, agricultural land, and ecological land should be adjusted and intensified. We should also pay more attention to the population transfer and other policy adjustments, adapt to and improve the changes in the environment of human settlements caused by future construction land saturation.

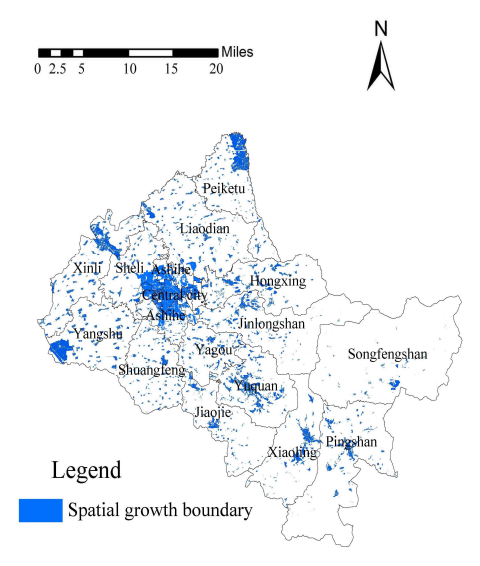

(a)

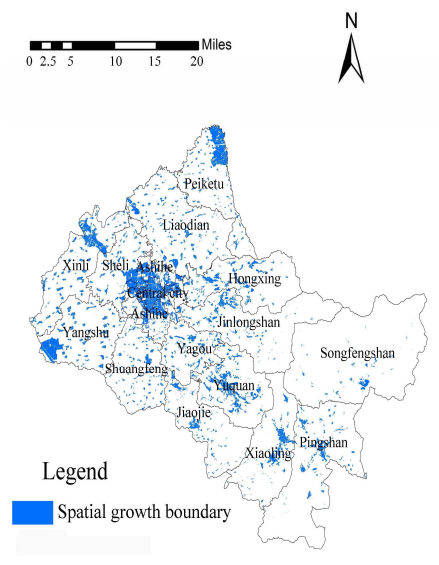

(b)

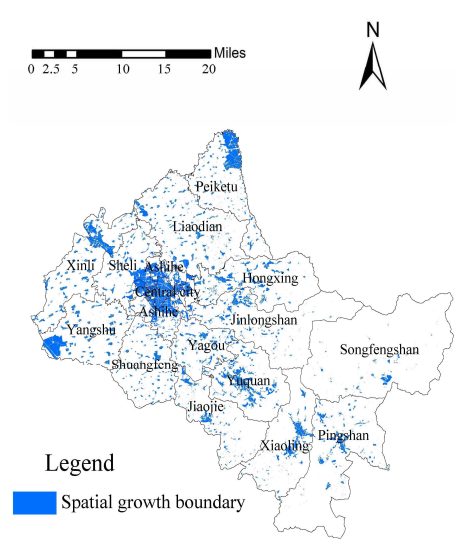

(c)

Figure 2. Zoning map of urban growth boundary. (a) Simulation results of the municipal administrative area spatial zoning model (M-MSZ) model; (b) Simulation results of traditional urban growth boundary (UGB) model; (c) Government behavior results.

\subsubsection{Land Use Planning}

Figure $3 a$ is generated by substituting the data of the study area into the MAA spatial zoning model. Compared with Figure $3 b$, which is simulated by the widely used land use planning model [43,73-76]. The application method of CA in land use planning is shown in Section 3.1.1. The kappa value of comparison was calculated to be $83.3 \%$. The difference exists in the living space of the suburbs, especially in the eastern suburbs. The main reason for the difference is that the purpose of the M-MSZ model is to divide the suitability of MAA spatial development. Additionally, the high objectivity of the 11 factor weights in the M-MSZ model results in the detailed division of the land use space. Through regression analysis of the M-MSZ model and the contrasting land use planning model, it is found that the $\mathrm{R}^{2}$ value of the M-MSZ model is 0.83 , and the $\mathrm{R}^{2}$ value of the contrast model is 0.79 , which proves that the M-MSZ model is more objective than the contrasting model in the actual fitting process. The objective characteristics of the M-MSZ model can provide more objective and detailed spatial function orientation for land use in villages and towns, with higher factor weights. When compared with the government behavior, the kappa value is calculated to be $85.1 \%$, which shows that the M-MSZ model plays an important guiding role in the simulation of the land use planning of the village-town system. At the same time, it verifies that the government behavior is scientific. According to these results, we suggest that this region should be transformed into a long-term urban development space to make reservations for future urban construction land, so as to avoid the limitation of land use in the future because of land use planning and ecological environmental protection planning. Meanwhile, considering that the current urban and rural planning is limited to 2030, and the predicted period of the M-MSZ model is 50 years, it is suggested that the reserved future urban construction land can be used as general farmland for agricultural production or non-limiting landscape ecological land. 


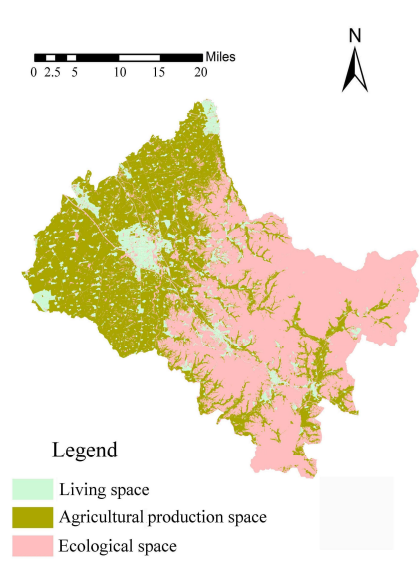

(a)

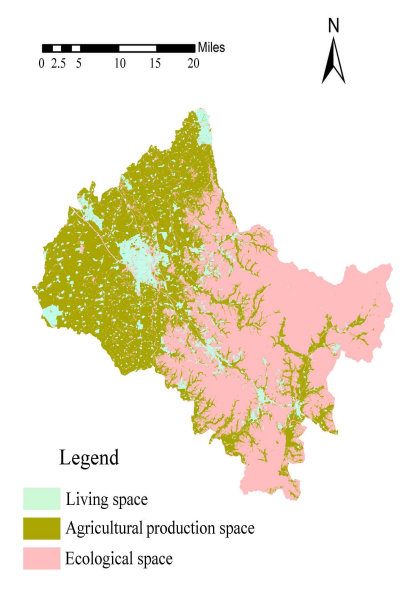

(b)

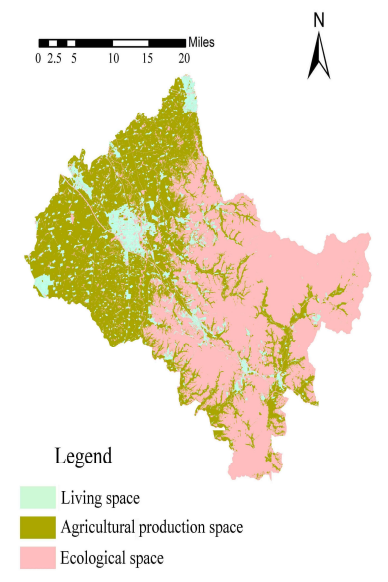

(c)

Figure 3. Land use planning map. (a) The simulation results of the M-MSZ model; (b) The simulation results of traditional land use planning model; (c) Government behavior results.

\subsubsection{Spatial Governance Zoning}

Based on the principle of maximizing the development of living space and protection, the M-MSZ model and the widely used space governance zoning models [77-79] are used to calculate the development suitability. Here, the space units, with development suitability of the first and second class in the calculation results of the M-MSZ model, are regarded as a suitable development area, and the space units, with the development suitability of the third- and fourth-class space units, are regarded as a limited development zone. The fifth-class space units are considered as a prohibited development zone, as shown in Figure 4a,b. The results show that the Kappa value of the model and the contrasting model is $76.3 \%$, and the image consistency is high. This proves the accuracy of the M-MSZ model. Meanwhile, there are also differences. The main reason for the difference is that the M-MSZ model refines the major functional areas of the city and combines the limitation of the major functional areas with spatial development suitability zoning. Furthermore, it divides the spatial governance zoning of the village-town system on the basis of spatial development suitability, instead of the direct determination of the limited development zone and suitable development zone by the traditional spatial governance zoning model. Due to the importance of economic conditions, population, available land resources, location, and traffic factors in the M-MSZ model, it is more accurate than the contrasting spatial governance zoning model in areas where there is a dense population, more available land, and a high per capita GDP, as well as areas that surround urban areas, railways, and high-speed roads. Moreover, the M-MSZ model takes advantage of the logical deduction of the factors, which greatly reduces the subjectivity of factor selection in the traditional spatial governance zoning model. This improvement makes it superior to the traditional spatial governance zoning model in the objective expression of MAA spatial zoning mechanism. Through regression analysis of the M-MSZ model and the contrasting spatial governance zoning model, it is found that the $R^{2}$ value of the M-MSZ model is 0.81 , while that of the contrasting model is 0.80 . This proved that the M-MSZ model is more objective than the contrasting model in the fitting process. When compared with the government behavior (Figure 4c), the kappa value is $74.2 \%$, which means that the simulation of the M-MSZ model basically coincides with the intention of the government. Then, we suggest that preparations for construction land should be made in areas with good economic conditions, a large population, a large amount of available land resources, an obvious location, and transportation advantages. These areas are much more likely to be transformed into suitable construction areas, before other areas. Meanwhile, we should make preparations for land compatibility in other suitable construction areas, while reserving temporary land reserves, such as temporary warehouses, etc. 


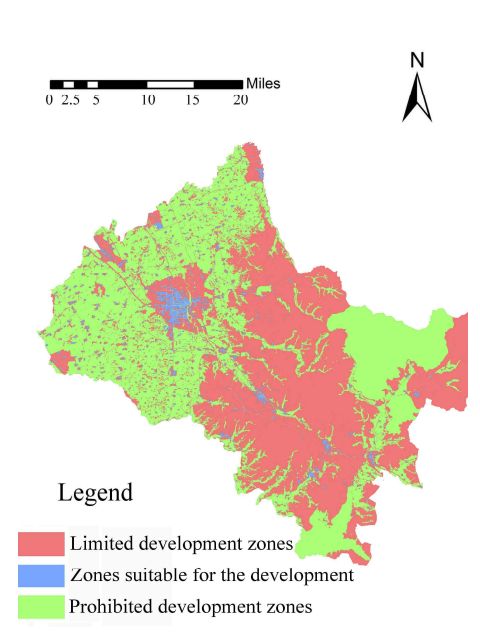

(a)

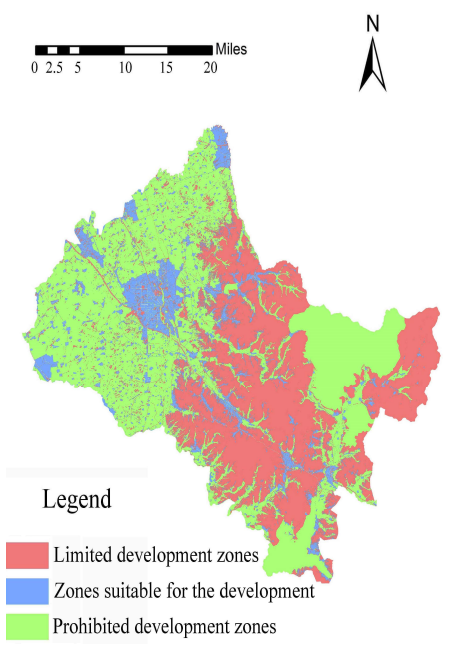

(b)

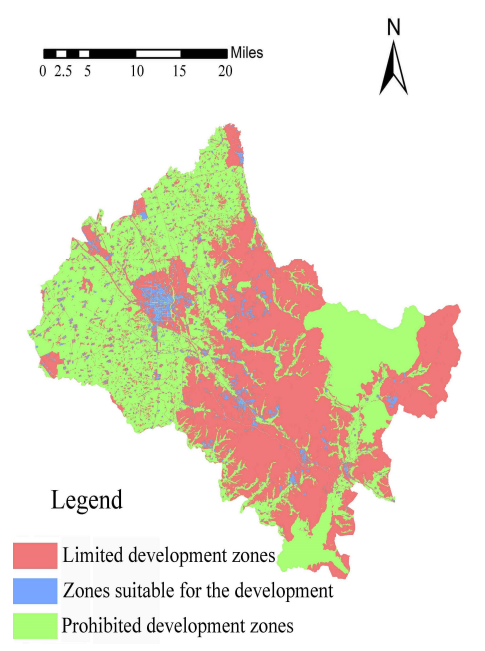

(c)

Figure 4. Spatial governance zoning map. (a) The simulation results of the M-MSZ model; (b) The simulation results of traditional spatial governance zoning model; (c) Government behavior results.

\subsubsection{Key Village-town Planning}

Due to the consideration of MAA spatial development, the M-MSZ model can be used to classify the key development areas and the key villages and towns, so as to improve the planning of key villages and towns. Figure 5a shows a key village-town planning map, generated by applying the M-MSZ model. Figure 5b shows a key village-town planning map, generated by Ren Guoping's gravitational model [57], which is universal [80]. After the comparison, the kappa value is calculated to be $87.7 \%$, and the consistency test value of the two maps is high. By comparing the two models, it is found that the differences are mainly caused by the basic role of the spatial development suitability and the objectivity of the M-MSZ model. The regression analysis of the M-MSZ model and the contrasting model shows that the $\mathrm{R}^{2}$ value of the M-MSZ model is 0.84 , and the $\mathrm{R}^{2}$ value of the contrasting model is 0.83 , which proves that the M-MSZ model is more objective than the contrasting model. On the other hand, the introduction of the spatial development suitability of the M-MSZ model is more detailed in the planning of key villages and towns, and it can reflect the most recent development areas, villages, and towns in detail. This provides a more specific guidance for the selection and planning of key villages and towns. In sum, the M-MSZ model is superior to the contrasting model in terms of spatial and temporal refinement. From Figure $5 a, b$, we can see that the kappa value of the M-MSZ model and the government behavior is $81.2 \%$, which means that the M-MSZ model simulation is basically consistent with the government intention. Therefore, we suggest that Ashihe, Xinli, Peiketu, Yuquan, Pingshan, and Hongxing should be the first-level key development towns; Yagou, Yangshu, Jiaojie, Xiaoling, and Sheli should be the second-level key development towns; and Jinlong Mountain, Songfeng Mountain, Shuangfeng, and Liaodian should be the third-level key development towns. According to the distance between the towns and central urban areas, we divide the towns into different phases. In the first-level key development towns, Ashe River, Xinli, Yuquan, and Hongxing are regarded as first-phase development towns, while Peiketu and Pingshan are regarded as second-phase development towns. In the second-level key development towns, Yagou, Yangshu, Jiaojie, and Sheli are regarded as first-phase development towns, and Xiaoling ia regarded as a second-phase development town. As for third-level key development towns, Jinlongshan, Shuangfeng, and Liaodian are regarded as first-phase development towns, while Songfeng Mountain is regarded as a second-phase development town. 


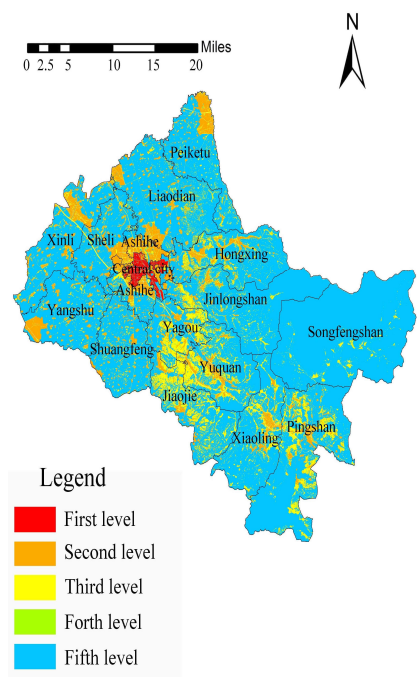

(a)

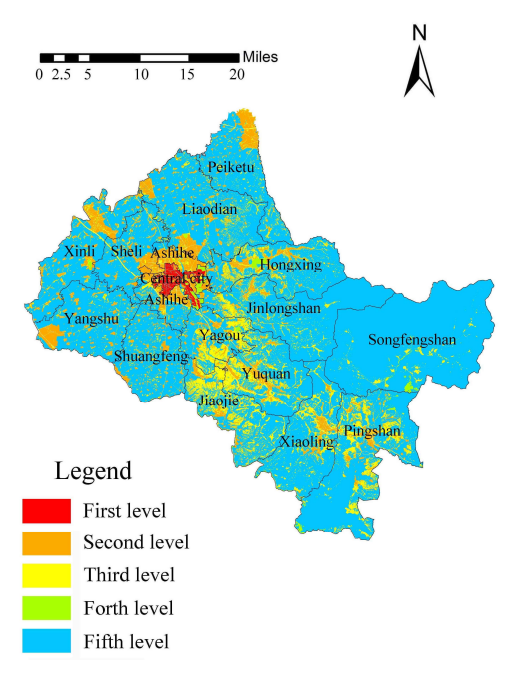

(b)

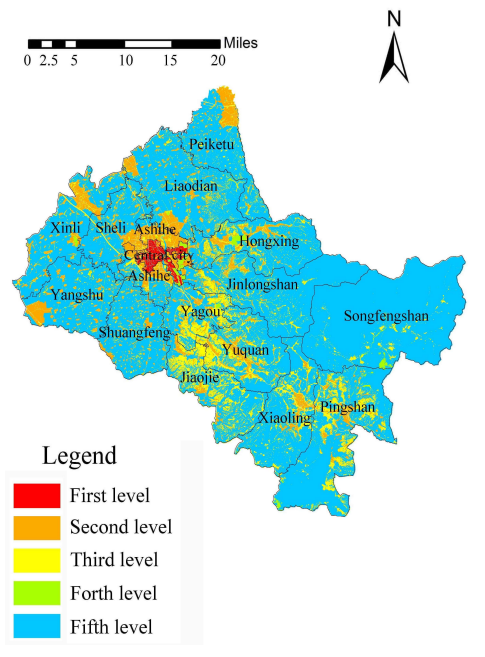

(c)

Figure 5. Key village-town planning map. (a) The simulation result of the M-MSZ model; (b) the simulation result of traditional gravitational model; (c) The government behavior results.

\subsubsection{Industrial Land Layout}

Using the M-MSZ model to divide EPLs, an industrial land layout of the village-town system can be made. Based on the principle of giving consideration to both development and protection, the M-MSZ model and the contrasting gravity model $[58,81]$ are applied to simulate the industrial land distribution in the study area, and the results are shown in Figure 6a,b, respectively. Comparing the two graphs, the kappa value is calculated to be $72.3 \%$, and the consistency test value is high. This proves the accuracy of the M-MSZ model. Meanwhile, there are also differences. In our understanding, the reasons for the differences are mainly the different starting point and the purpose of the model construction. The contrasting model is based on the attraction of regions to related industries and aims at the layout of industrial land, while the M-MSZ model is based on the suitability of development and aims at the zoning of EPLs. The organic combination of the suitability and EPL zoning is characteristic of the M-MSZ model, which successfully generates a layout of industrial land in the village-town system on the background of macro EPLs. This provides a reliable way of thinking and avoids the occurrence of the phenomenon of violating the major function of macro-space. On the background of macro living space and agricultural space, the suitability of zoning development can provide a reference for the macro layout of the first, second, and third industries, as well as the development level and timing-order of the medium-sized development. The application results show that the contrasting model usually divides the industrial land distribution of the village-town system macroscopically and generally distinguishes the primary and secondary production. The M-MSZ model optimizes the macroscopicity of the contrast model in the industrial land use zoning of the village-town system. To maintain macroscopicity, the same industrial land is graded and refined to guide the development timing-order of related industries and the corresponding site selection of large-scale industries. Moreover, by positioning the living space, it provides better suggestions for the medium-sized location of Sanchan. Comparing Figure $6 a, c$, the kappa value is calculated to be $74.1 \%$, which means that the M-MSZ model simulation is basically consistent with the government's intention. According to the results, we suggest that the northwestern areas of Ashihe, Xiaoling, Peiketu, and Yangshu should be the key development areas of secondary and tertiary industries, and the central areas of Shuangfeng, Yagou, and Hongxing should be the key development areas of the primary industry. 


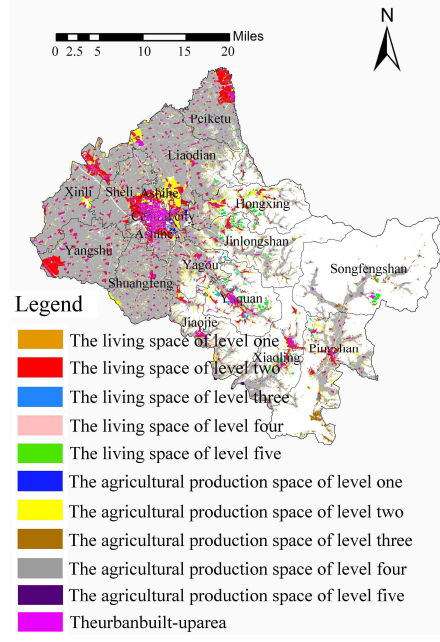

(a)

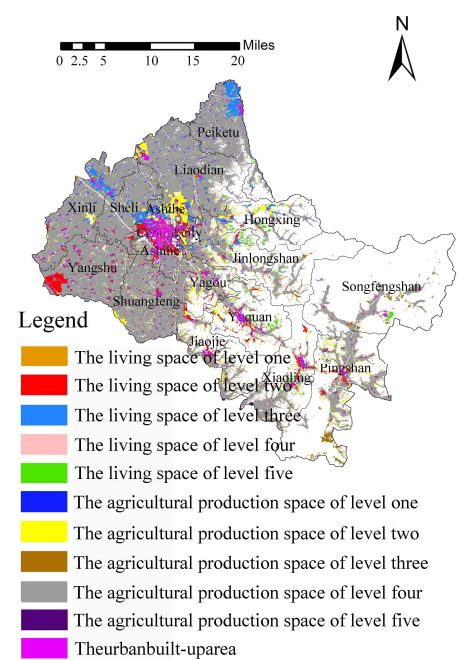

(b)

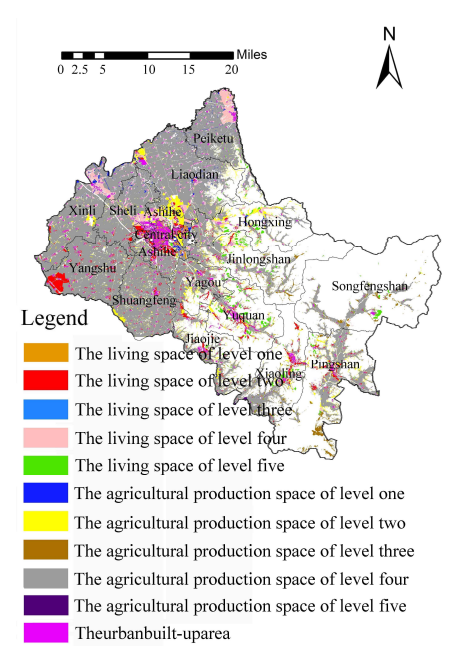

(c)

Figure 6. Industrial land layout map. (a) The simulation result of the M-MSZ model; (b) The simulation result of traditional gravity model; (c) The government behavior results.

\subsubsection{Location and Layout of Village Relocation and Consolidation}

The M-MSZ model is constructed based on the suitability of MAA spatial development, so it can divide the spatial development grade of the village-town system. Hence, it can be used to make the statistics of the land suitable for the development of the village, thus promoting the implementation of village relocation and consolidation. By combining the distance among villages and towns and the policy direction, considering the principle of relocation nearby and within the administrative region and the available land resources, the M-MSZ model and the contrasting model $[59,82,83]$ are applied to the study area. The results are shown in Figure $7 \mathrm{a}, \mathrm{b}$. It is found that the kappa value is calculated to be $80.4 \%$, which is attributed to the introduction of the development suitability and major function limitation. Moreover, the M-MSZ model is more precise and shows a better timing-order than the traditional contrasting model in the classification of village site selection. In conclusion, the M-MSZ model not only retains the function of village relocation and consolidation of the contrasting model, but also the development suitability and major function of the M-MSZ model, further refining the different land attribution. The refined results can solve the problem of the direction of village relocation and consolidation on a meso-scale, under the macro guidance of the contrasting model. In addition, the M-MSZ model can also provide useful information on the timing-order of the village location by combining the urgency of relocating villages and towns and a key village-town planning map (Figure 5a), referring to the level of land used at the village location. Comparing the merger planning of the village-town system relocated by the government, as shown in Figure 7a,c, the kappa value is calculated to be $87.7 \%$. The main difference is in the western region, which is mainly affected by the adjustment policy of the provincial capital administrative divisions. If this area is excluded, the kappa value is calculated to be $81.2 \%$. According to the above results, we suggest that Xinrong Village be merged into Pektu Central Town, Ketu Village be merged into Sheli Village, New Village into Xuedian Central Town, Taiping Village into Sheli Central Town, Wuxing Village into Xinli Central Town, Changhong Village and Liping Village into Xianfeng Village, Hongqi Village into Yangshu Central Town, Ping'an Village and Chengjian Village into Central Town, Revitalizing Village into Hongxing Central Town, and Xianfeng Village into Fuxing Village. Further, Jixing Village should be merged into Jinlongshan Central Town, Gaosheng Village and Xingguang Village into Yagou Central Town, Shuanglan Village into Shuangfeng Central Town, Jiaojie Village into Jiaojie Central Town, Shifa into Xiaoling Central Town, Pingshan Village, Xingguang Village and Shuanghe Village into Pingshan Central Town, and Songfeng Village into Songfeng Mountain Central Town. First, the villages and towns that have been incorporated into the central urban area, Xinli Street and Peiketu Town, could 
be cancelled and merged. Then, the villages that have been incorporated into Yangshu Town, Yagou Town, Hongxing Town, Jianjie Town, Xiaoling Town, and Pingshan Town can be canceled and merged. Finally, the villages and towns in Jinlongshan Town, Songfeng Mountain Town, and Pingshan Town can be canceled and merged.

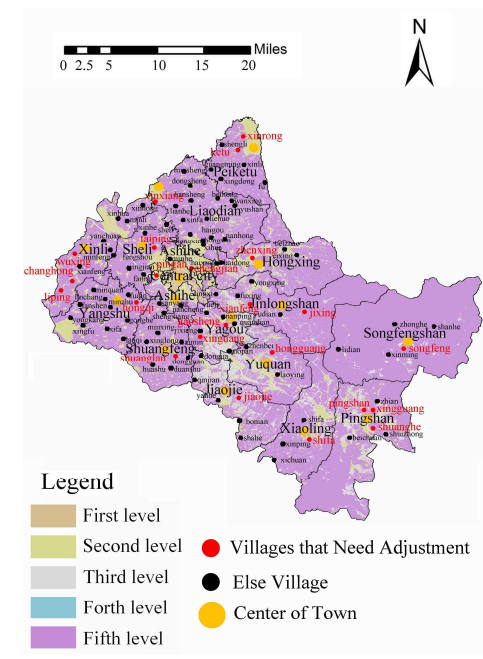

(a)

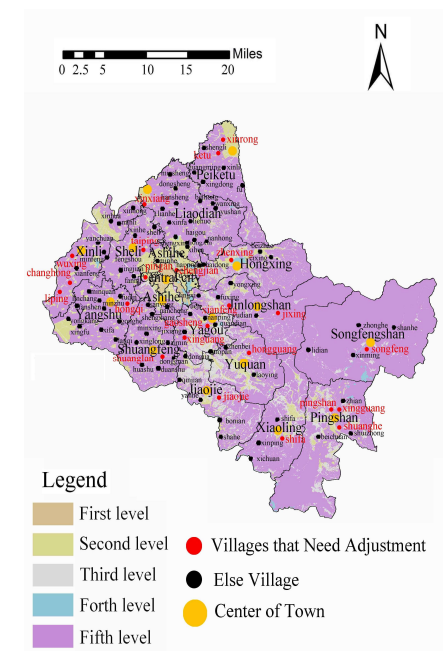

(b)

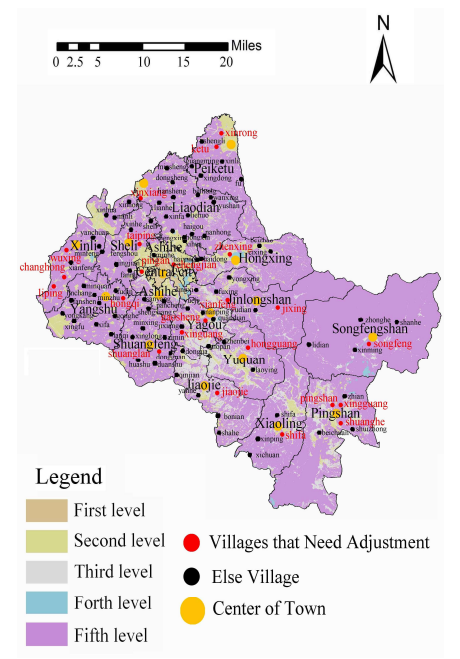

(c)

Figure 7. Industrial land layout map. (a) The simulation result of the M-MSZ model; (b) The simulation result of traditional gravity model; (c) The government behavior results.

\subsubsection{Timing-order of MAA Development}

Because of the particularity of the M-MSZ model in evaluating the suitability of land use development, the M-MSZ model can be used to predict the timing-order of MAA spatial development. We extract the divided living space and search for the topological relationship between the transitional zone and the built-up area. Here, the transitional zone adjacent to the first-class built-up area were regarded as the first development zone. By analogy, we choose the adjacent area first and then the grade of the M-MSZ model results, so as to generate the MAA spatial development timing-order, as shown as in Figure 8a,b. When compared with the development suitability zoning model to simulate the spatial development timing-order [61,84-87], the kappa value was calculated to be $75.7 \%$. This proves the accuracy of the M-MSZ model. Meanwhile, there are also differences. The main reason for the difference is the objective deduction of the factors in the construction of the M-MSZ model. The regression analysis of the M-MSZ model and the contrasting model shows that the $\mathrm{R}^{2}$ value of the M-MSZ model is 0.78 , and the $R^{2}$ value of the contrasting model is 0.77 , which proves that the M-MSZ model is more objective than the contrasting model. When compared with the government action, the kappa value is calculated to be $85.1 \%$, and the consistency is high. From Figure 8a, it can be seen that it is better to develop the central city and Ashihe, Xinli, Yuquan, Hongxing, and Sheli streets first, as well as Yagou, Yangshu, Jiaojie streets, and then proceed to develop the towns of Peiketu, Pingshan, and Xiaoling second. Finally, Jinlong Mountain, Shuangfeng, Liaodian, and Songfeng Mountain should be developed. This coincides with the intentions of the planning department and the local government. 


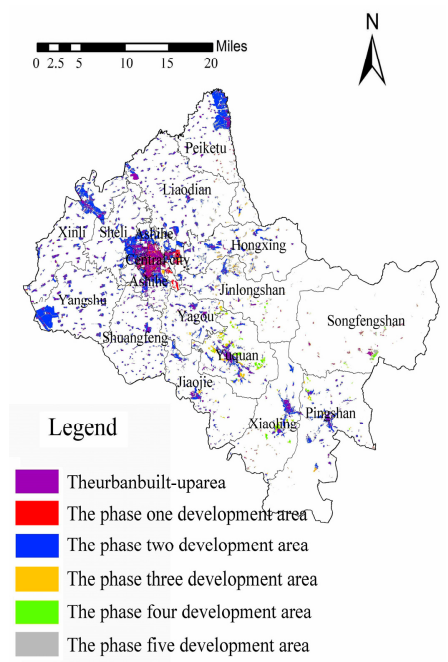

(a)

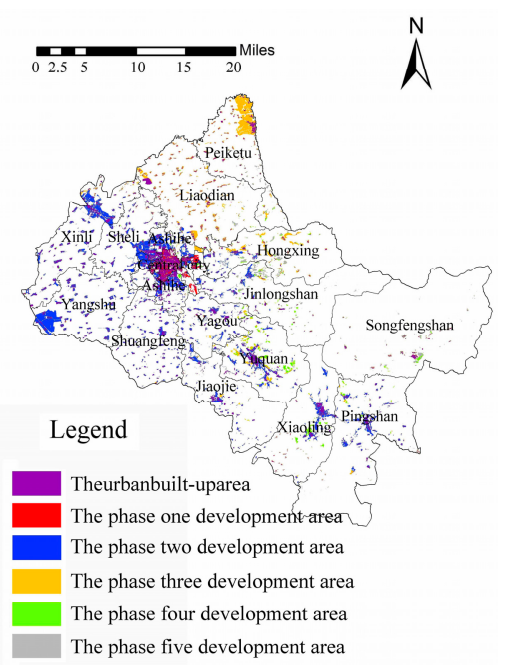

(b)

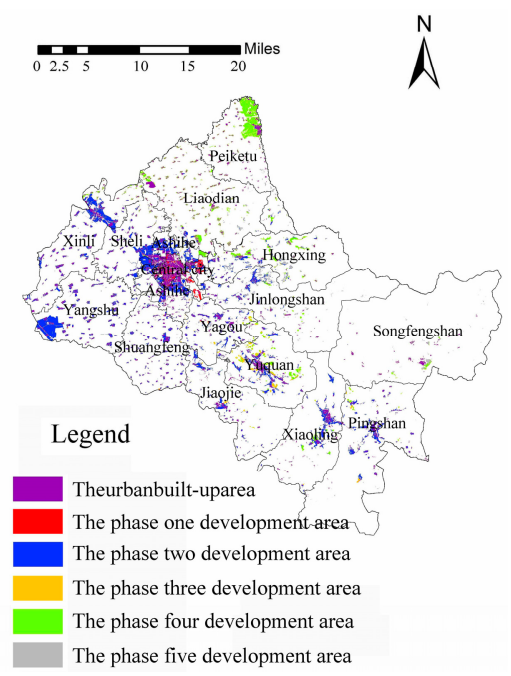

(c)

Figure 8. Municipal administrative area (MAA) development timing-order map. (a) The simulation result of the M-MSZ model; (b) The simulation result of traditional development suitability zoning model; (c) The government behavior results.

\subsubsection{Village-town Scale}

Using the M-MSZ model and the system dynamics model [33] to simulate the rigid development boundary of the living space of villages and towns over the next 50 years, the scale of villages and towns in the study area is obtained, as shown in Figure 9a,b, respectively. By comparison, the kappa value is calculated to be $84.7 \%$. The main reason for the difference is that the M-MSZ model introduces a limited function of the major function area, which gives the M-MSZ model outstanding advantages in the overall scale control of the city. Especially, the coupling between the limited development area of the major function and the transitional zone, as determined by the M-MSZ model, plays a greater role in the priority selection of the living space expansion of villages and towns. When compared with the government behavior (Figure 9c), the kappa value is calculated to be $83.5 \%$, and the consistency is high. Based on these results, we suggest that Songfeng Mountain, Jinlong Mountain, Pingshan, and Jiaojie Towns, which have less reserved living space, should appropriately consider the combination of surrounding villages and towns or intensive development.

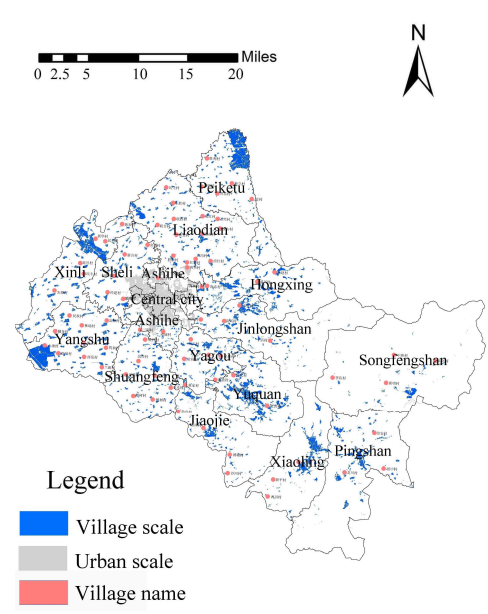

(a)

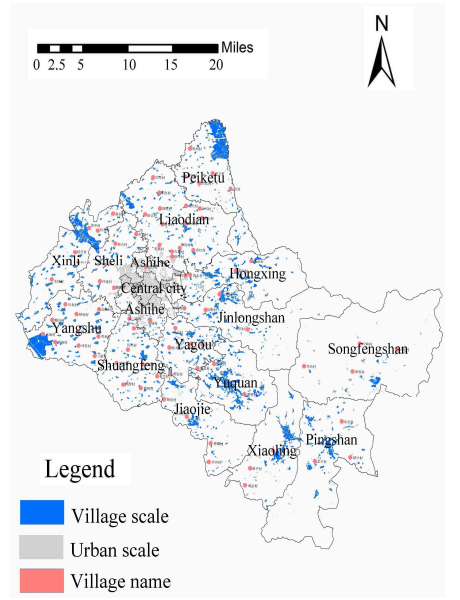

(b)

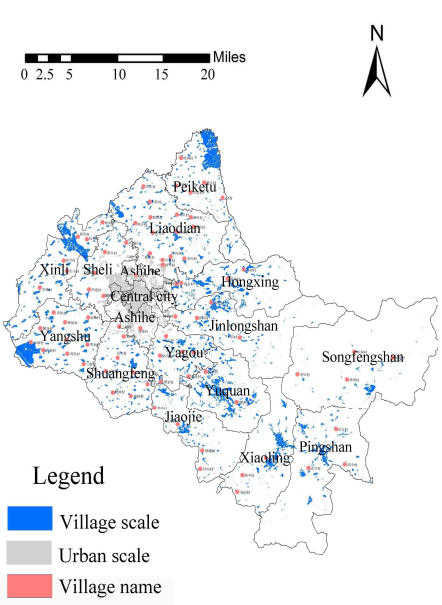

(c)

Figure 9. Village-town Scale Map. (a) The simulation results of the M-MSZ model; (b) The simulation results of traditional system dynamics model; (c) Government behavior results. 


\subsubsection{Functional Orientation of Villages and Towns in MAA}

First, the M-MSZ model is used to calculate the development suitability grade of each factor in a village, and the factors of the development suitability of level 1-2 are selected as the dominant factors of the village. Meanwhile, the factor of the economic development level is refined to select the main economic sectors. Secondly, the major function of the EPLs map is positioned according to the proportion of living, production, and ecological space in villages and towns. For example, if the proportion of living space of a village is the largest, the major function is defined as a suitable development space; if the proportion of ecological protection space is the largest, it is defined as a suitable ecological protection space; and if the proportion of agricultural production space is the largest, it is defined as a suitable agricultural production space. Then, the dominant factors, the main economic departments, and the major function orientation of EPLs are superimposed, and the superimposed value is defined as the function of these villages and towns. Using Songfeng Mountain Town as an example, the development suitability of ecosystem vulnerability and natural environmental capacity factors is higher than that of other factors, all of which are first or second grade, and all of the other factors are below the second grade. The main economic department is the tourism service industry, and the ecological protection space of Songfeng Mountain Town accounts for the vast majority. Therefore, the function of Songfeng Mountain Town is defined as a town dominated by tourism.

The simulation results of the M-MSZ model, contrasting model, and the government behavior results were then compared, and the results are summarized in Table 2. As shown, the simulation result of the M-MSZ model tells us that the village-town function of several villages and towns should be as follows. The central urban area should be mainly involved in the Trade and Service, and Living and Logistics industries. Peiketu town should be mainly involved in the Food Processing, Logistics, Planting and Processing of Agricultural Products, and Trade and Service industries. Liaodian town should be mainly involved in the Trade and Service, Logistics, Planting and Processing of Agricultural Products, and Living industries. Jinlong town should mainly involve in the Tourism industry. These results are very similar to the government results. Comparatively, the simulation results of the contrasting model have a greater difference to the government behavior results.

The difference in the simulation results, between the M-MSZ model and contrasting model, is mainly caused by the coupling of the development suitability and EPLs in the M-MSZ model. The M-MSZ model not only retains the factor gravitation of the dynamic model, but also grasps the functions of villages and towns from the macro-positioning of EPLs, which makes the simulation more consistent with the functions of villages and towns, required by the village-town system. Under the guidance of macro-functions, the major functions of villages and towns are positioned on the basis of dominant factors, which reduces the possibility of a contradiction with the macro major functions that exist in the contrasting model. Meanwhile, compared with the contrasting model, the M-MSZ model has more advantages in the macro-limitation of spatial functions and the use of regional advantage factors to guide the functions of middle-level villages and towns. In view of the advantages of key towns and the geographical location of the city (near the provincial capital city), it is suggested that the functions of the urban area should be mainly developing trade, tourism, and the processing of agricultural products. 
Table 2. Comparison of the M-MSZ model, contrast model, and government behavior results on the function orientation.

\begin{tabular}{|c|c|c|c|c|c|}
\hline & Town & Central Urban Area & Peiketu Town & Liaodian Town & Jinlongshan Town \\
\hline \multirow{8}{*}{$\begin{array}{l}\text { Simulation } \\
\text { Results of the } \\
\text { M-MSZ Model }\end{array}$} & \multirow{5}{*}{$\begin{array}{l}\text { Dominant } \\
\text { Factors }\end{array}$} & First-level Economic Situation & First-level Economic Situation & First-level Economic Situation & First-level Ecosystem Vulnerability \\
\hline & & First-level Population Aggregation & First-level Population Aggregation & First-level Population Aggregation & First-level Economic Situation \\
\hline & & $\begin{array}{c}\text { First-level Transportation } \\
\text { Advantages }\end{array}$ & $\begin{array}{c}\text { Second-level Transportation } \\
\text { Advantages }\end{array}$ & $\begin{array}{c}\text { Second-level Transportation } \\
\text { Advantages }\end{array}$ & $\begin{array}{l}\text { Second-level Natural } \\
\text { Environmental Capacity }\end{array}$ \\
\hline & & First-level Location Advantage & Second-level Location Advantage & Second-level Location Advantage & $\begin{array}{l}\text { Second-level Transportation } \\
\text { Advantages }\end{array}$ \\
\hline & & $\begin{array}{l}\text { Number of Development Zones } \\
\text { That Is Not Built Up, Or } \\
\text { Development Zones Undeveloped } \\
\text { After Adjusted by the State or } \\
\text { Government, Second-level }\end{array}$ & $\begin{array}{c}\text { Second-level Available Land } \\
\text { Resources }\end{array}$ & $\begin{array}{l}\text { Second-level Available Land } \\
\text { Resources }\end{array}$ & Second-level Location Advantage \\
\hline & $\begin{array}{l}\text { Main Economic } \\
\text { Sectors }\end{array}$ & $\begin{array}{c}\text { Trade and Service industry, } \\
\text { Logistics }\end{array}$ & Food Processing and Logistics & $\begin{array}{c}\text { Logistics, Planting of Agricultural } \\
\text { Products, Trade and Service } \\
\text { industry }\end{array}$ & Tourism industry \\
\hline & $\begin{array}{l}\text { Major Function } \\
\text { Orientation }\end{array}$ & Suitable Development Space & $\begin{array}{l}\text { Suitable for Agricultural } \\
\text { Production Space }\end{array}$ & $\begin{array}{l}\text { Suitable for Agricultural } \\
\text { Production Space }\end{array}$ & $\begin{array}{l}\text { Suitable Ecological Protection } \\
\text { Space }\end{array}$ \\
\hline & $\begin{array}{c}\text { Function of the } \\
\text { M-MSZ }\end{array}$ & $\begin{array}{l}\text { Mainly on Trade and Service } \\
\text { industry, Living and Logistics }\end{array}$ & $\begin{array}{c}\text { Food Processing, Logistics, } \\
\text { Planting and Processing of } \\
\text { Agricultural Products, Trade and } \\
\text { Service industry }\end{array}$ & $\begin{array}{c}\text { Mainly on Trade and Service } \\
\text { industry, Logistics, Planting and } \\
\text { Processing of Agricultural } \\
\text { Products, Living }\end{array}$ & Mainly on the Tourism industry \\
\hline \multirow{2}{*}{$\begin{array}{l}\text { Simulation } \\
\text { Results of the } \\
\text { Contrast Model }\end{array}$} & $\begin{array}{l}\text { Main Attraction } \\
\text { Factor }\end{array}$ & $\begin{array}{l}\text { Central Urban Area, Trade and } \\
\text { Service industry, Logistics }\end{array}$ & $\begin{array}{c}\text { Food Processing, Logistics, } \\
\text { Planting and Processing of } \\
\text { Agricultural Products, Trade and } \\
\text { Service industry }\end{array}$ & $\begin{array}{c}\text { Trade and Service industry, } \\
\text { Logistics, Planting of Agricultural } \\
\text { Products }\end{array}$ & Tourism Industry \\
\hline & $\begin{array}{l}\text { Function of the } \\
\text { contrast model }\end{array}$ & $\begin{array}{l}\text { Mainly on Trade and Service } \\
\text { industry, Logistics }\end{array}$ & $\begin{array}{l}\text { Mainly on Food Processing, } \\
\text { Logistics, Planting and Processing } \\
\text { of Agricultural Products, Trade and } \\
\text { Service industry }\end{array}$ & $\begin{array}{l}\text { Mainly on Trade, Logistics, } \\
\text { Planting of Agricultural Products }\end{array}$ & Mainly on the Tourism industry \\
\hline $\begin{array}{l}\text { Government } \\
\text { Behavior } \\
\text { Results }\end{array}$ & $\begin{array}{l}\text { Function of } \\
\text { Government } \\
\text { Planning }\end{array}$ & $\begin{array}{c}\text { Mainly on Tourism, Trade and } \\
\text { Service industry, Living and } \\
\text { Logistics }\end{array}$ & $\begin{array}{l}\text { Food Processing, Logistics, Trade } \\
\text { and Service industry, Living }\end{array}$ & $\begin{array}{l}\text { Mainly on Trade, Logistics, } \\
\text { Planting of Agricultural Products }\end{array}$ & Mainly on the Tourism industry \\
\hline
\end{tabular}




\section{Discussion}

According to the current research, village-town system planning has not formed a relatively perfect experience or model [23]. For a long time, the methods and concepts associated with village-town system planning drew lessons from city system planning to a great extent. However, village-town system planning is different from city system planning in terms of content and purpose [88-90]. Based on the concepts of urban population, place, environment, resource protection, and sustainable development, we built the M-MSZ model by unifying the decentralized urban system planning models. This model realizes the objectivity of weight assignment, high objectivity, accuracy, and efficiency in solving the key problems of rural system planning. This paper analyzes the correctness, superiority, and application value of the M-MSZ model in the planning of a village-town system by applying it in the village-town spatial planning of a city, located in the south of Heilongjiang province.

\subsection{The Explanation Degree of the M-MSZ Model Compared with the Contrasting Models and Government Behavior}

Here, we apply the M-MSZ model to an MAA in the south of Heilongjiang Province. The urban growth boundary zoning map, land use planning map, spatial governance zoning map, MAA development timing-order map, key village-town planning map, industrial land layout map, location and layout map of village relocation and consolidation, village-town functional location map of MAA, and the village-town scale map are generated. The consistency Kappa values are shown in Table 3. The average Kappa value is $82.1 \%$, which tells us that the value of the M-MSZ model is in good agreement with that of the contrasting models and government behavior. Moreover, the comparison results show that most of the Kappa values of the contrasting models in relation to the government behavior results are smaller than that of the M-MSZ model in relation to the government behavior results. These results prove the correctness of the M-MSZ model and its better agreement with reality.

\subsection{Model Superiority}

When compared with the traditional UGB model, it is found that the M-MSZ model is more detailed than the contrasting model in zoning the urban growth boundary of the transitional zone between villages and towns due to its limitation on the major function. In addition, the M-MSZ model can be used to divide the EPLs, while the traditional UGB model can only divide the living space. Therefore, its application scope is better than the traditional UGB model.

When compared with the traditional land use planning model, it is found that the M-MSZ model is more detailed and objective than the land use planning model in zoning the system space of villages, because of its consideration of development suitability and the higher objectivity of parameters and factor weights. Moreover, the M-MSZ model can also deepen the long-term planning of land use planning in village-town system planning. In particular, it can guide the future reserve of construction land for villages and towns and reduce the possibility of a contradiction between land use planning and ecological environmental protection planning in the future.

When compared with the traditional spatial governance zoning model, it is found that the M-MSZ model is more detailed in the analysis of densely populated areas, areas with more available land, areas with a higher per capita GDP, the surrounding areas of urban areas, and the regions along railways and high-speed roads. This is mainly attributed to the important position of the five factors in the M-MSZ model, including population, economy, available land resources, location, and transportation. This means that, for villages and towns with poor economic conditions, when the regional economy is facing various constraints, it is necessary to concentrate limited resources to break through some limiting factors at the right time. Particularly, those factors with a high contribution rate to the effectiveness of land zoning should be treated first, such as location advantage, population, available land resources, transportation advantage, etc., in order to achieve the goal of the rapid development of the region. When the factors with a high contribution rate to the M-MSZ model, such as economic conditions and location, are in a low limiting state, other limiting factors, especially the environmental factors, 
should be paid much more attention, so as to avoid the disorderly and unlimited development of villages and towns by developers. The principle of the coexistence of development and protection should be followed, and the space of villages and towns should be developed in a long-term and comprehensive way. At the same time, the coupling of the limitation of the major functional areas, and the spatial development suitability zoning in the M-MSZ model, has provided effective guidance for the macro-control of the refinement of the spatial governance zoning of villages and towns and the spatial governance zoning of villages and towns.

When compared with the traditional location, layout, and planning models of major regions, it is found that the timing-order zoning effect of the major regional layout and planning of villages and towns is also significant due to the organic coincidence of the zoning of EPLs, the limitation of major functions, and the suitability of spatial development. The M-MSZ model not only can guide villages and towns in merging or relocation, addressing relocation, locating key areas, and generating the layout of industrial land, but can also determine the key development areas by combining the final zoning period with the period of urban planning. Lastly, it can direct the timing-order of the priority distribution of industrial land and relocation and consolidate the approximate time of the relocation of villages and towns.

Moreover, it is found that the M-MSZ model can effectively reduce the possibility of the rapid or slow development of some village regions, while dividing the development timing-order of villages and towns.

When comparing the M-MSZ model with the traditional scale and function zoning models, it is found that some economic factors in the traditional model, such as the number of enterprises, consumer preferences, etc., are not easy to assign. The M-MSZ model effectively combines the economic model with the geographical model, which makes the impact factors easy to assign. Therefore, it effectively improves the application practicality of the M-MSZ model. At the same time, the zoning results of the M-MSZ model are more detailed than those of the traditional models. This could be attributed to the limited role of the suitability of spatial development and the major functional areas, as well the objectivity of the model construction.

In addition, in order to verify the objectivity of the M-MSZ model, this paper uses the M-MSZ model and the contrasting model to carry out multiple non-linear regression analysis and linear regression analysis, respectively, and compare the regression determinant coefficient $R^{2}$, as shown in Table 3. It is found that the $\mathrm{R}^{2}$ of the M-MSZ model is higher than the average $\mathrm{R}^{2}$ value of the six comparison models, which also verifies that the objectivity of the M-MSZ model is better than that of the above comparison model.

Table 3. Comparison of Kappa values.

\begin{tabular}{ccccccc}
\hline & & \multicolumn{3}{c}{ Kappa Value } & & \\
\cline { 3 - 4 } $\begin{array}{c}\text { Village-town } \\
\text { System Planning }\end{array}$ & $\begin{array}{c}\text { The Contrast } \\
\text { Model }\end{array}$ & $\begin{array}{c}\text { The } \\
\text { MMA-SZ } \\
\text { Model \& } \\
\text { Contrast } \\
\text { Model }\end{array}$ & $\begin{array}{c}\text { The } \\
\text { MMA-SZ } \\
\text { Model \& } \\
\text { Government } \\
\text { Behavior }\end{array}$ & $\begin{array}{c}\text { Contrast } \\
\text { Model \& } \\
\text { Government } \\
\text { Behavior }\end{array}$ & $\begin{array}{c}\mathbf{R}^{2} \text { of the } \\
\text { MMA-SZ } \\
\text { Model }\end{array}$ & $\begin{array}{c}\mathbf{R}^{2} \text { of the } \\
\text { Contrast } \\
\text { Model }\end{array}$ \\
\hline $\begin{array}{c}\text { Urban growth } \\
\text { boundary Zoning }\end{array}$ & UGB model & $78.20 \%$ & $83.80 \%$ & $77.60 \%$ & 0.77 & 0.75 \\
\hline $\begin{array}{c}\text { Land Use } \\
\text { Planning }\end{array}$ & $\begin{array}{c}\text { Land Use } \\
\text { Planning Model }\end{array}$ & $83.30 \%$ & $85.10 \%$ & $80.24 \%$ & 0.83 & 0.79 \\
\hline $\begin{array}{c}\text { Spatial } \\
\text { Governance } \\
\text { Zoning }\end{array}$ & $\begin{array}{c}\text { Spatial } \\
\text { Governance } \\
\text { Zoning Model }\end{array}$ & $89.30 \%$ & $84.20 \%$ & $81.20 \%$ & 0.81 & 0.80 \\
\hline $\begin{array}{c}\text { MAA } \\
\begin{array}{c}\text { Development } \\
\text { Timing-order }\end{array}\end{array}$ & $\begin{array}{c}\text { Development } \\
\text { Timing-order and } \\
\text { Zoning Model }\end{array}$ & $75.70 \%$ & $85.10 \%$ & $83.40 \%$ & 0.78 & 0.77 \\
\hline
\end{tabular}


Table 3. Cont.

\begin{tabular}{|c|c|c|c|c|c|c|}
\hline \multirow[b]{2}{*}{$\begin{array}{l}\text { Village-town } \\
\text { System Planning }\end{array}$} & \multirow[b]{2}{*}{$\begin{array}{c}\text { The Contrast } \\
\text { Model }\end{array}$} & \multicolumn{3}{|c|}{ Kappa Value } & \multirow[b]{2}{*}{$\begin{array}{c}\mathrm{R}^{2} \text { of the } \\
\text { MMA-SZ } \\
\text { Model }\end{array}$} & \multirow[b]{2}{*}{$\begin{array}{c}\mathrm{R}^{2} \text { of the } \\
\text { Contrast } \\
\text { Model }\end{array}$} \\
\hline & & $\begin{array}{c}\text { The } \\
\text { MMA-SZ } \\
\text { Model \& } \\
\text { Contrast } \\
\text { Model }\end{array}$ & $\begin{array}{c}\text { The } \\
\text { MMA-SZ } \\
\text { Model \& } \\
\text { Government } \\
\text { Behavior }\end{array}$ & $\begin{array}{l}\text { Contrast } \\
\text { Model \& } \\
\text { Government } \\
\text { Behavior }\end{array}$ & & \\
\hline $\begin{array}{l}\text { Key Village-Town } \\
\text { Planning }\end{array}$ & \multirow{3}{*}{$\begin{array}{l}\text { Various Models } \\
\text { for Location and } \\
\text { Layout }\end{array}$} & $87.70 \%$ & $81.20 \%$ & $81.40 \%$ & 0.84 & 0.83 \\
\hline $\begin{array}{c}\text { Industrial Land } \\
\text { Layout }\end{array}$ & & $82.30 \%$ & $84.10 \%$ & $83.50 \%$ & 0.69 & 0.69 \\
\hline $\begin{array}{l}\text { Location and } \\
\text { Layout of Village } \\
\text { Relocation and } \\
\text { Consolidation }\end{array}$ & & $79.40 \%$ & $81.40 \%$ & $79.50 \%$ & 0.75 & 0.76 \\
\hline Village-town scale & $\begin{array}{c}\text { Scale-Level and } \\
\text { Functional Zoning } \\
\text { Model }\end{array}$ & $84.7 \%$ & $83.5 \%$ & $82.6 \%$ & 0.82 & 0.81 \\
\hline
\end{tabular}

Overall, the M-MSZ model unifies the application functions of the six traditional MAA spatial zoning models, namely, the scale and function zoning model, UGB model, land use planning model, spatial governance zoning model, location of major regions, layout and planning model, development timing-order and zoning model. In application, it avoids the conflict of time and space caused by different model parameters, leading factors, etc. At the same time, the unified model of MAA spatial zoning not only saves costs, but also benefits the compilation of village-town planning and the operation and implementation of managers. Due to the introduction of space development suitability, major function, the purpose of the zoning of EPLs, and the objective expression of a large number of parameters and factor weights, the M-MSZ model showed itself to be more detailed and objective than the five traditional MAA spatial zoning models (including the UGB model, land use planning model, spatial governance zoning model, location of major regions, layout and planning model, and MAA development timing-order model) in the explanation of the key points of village-town system planning. Moreover, the M-MSZ model avoids some factors that are not easy to assign, while retaining the dominant factors of the scale and function zoning model, which makes the M-MSZ model easier to apply.

\subsection{Application Scope and Inheritance of the M-MSZ Model}

We believe that the M-MSZ model has greater generalization and inheritance in application, as well as a great field, because of the certainty of the impact factors and weight assignment. The M-MSZ model not only has a good application value in the planning of villages and towns, but also performs well in guiding the urban scale, function, and key city construction of urban planning, which can provide an efficient and unified reference basis for urban-rural co-ordination and the acceleration of the process of urban-rural integration. Meanwhile, special planning in village-town system planning, such as facilities allocation, tourism, disaster prevention, and historical and cultural protection, can also be added to the M-MSZ model to further guide the compilation and implementation of special planning. In future research, researches will focus on the solution of model-specific planning problems, so as to achieve a truly unified planning model of villages and towns.

\subsection{Enlightenment in the Development Modelling of Towns}

The M-MSZ model not only enriches the equilibrium theory, but also provides new ideas for the development model of Chinese villages and towns. The application results show that the M-MSZ model can effectively and reasonably zone the space of villages and towns, from the perspective of macro-equilibrium, and can effectively reduce the possibility of overtime or delay of development 
through the MAA spatial development time. This promotes the intensive development of village-town land and provides an effective reference for the development of village-town space with economic strength, while reducing the possibility of delaying development. Using the unified M-MSZ model, the horizontal comparison of each village-town system can provide a basis for the evaluation of MAA competitiveness. In addition, it can also provide a scientific basis for future development directions in relation to different levels of villages and towns.

\section{Conclusions}

From the above application results, the M-MSZ model not only can simulate various spatial zoning of villages and towns but can also divide the development timing-order of village space from the perspective of development suitability. The M-MSZ model and the traditional MAA spatial zoning models are discussed. The consistency Kappa values compared with the UGB model, land use planning model, spatial governance zoning model, and location selection of major regions are $78.2 \%$, $83.3 \%, 82.3 \%, 79.8 \%, 75.7 \%$, and $83.9 \%$, respectively, and the average Kappa value is $80.5 \%$. This proves the accuracy of the M-MSZ model. Meanwhile, there are also differences. The main reasons for the differences are the development suitability, the introduction of a limitation in major functional areas, and the objectification of the model parameters and factor weights of the M-MSZ model. We believe that the M-MSZ model has a strong applicability in the planning of village-town systems, because it can grasp the core contents of the planning of village-town systems (various kinds of forecasting, urban land zoning and layout, urban development timing-order, location selection, layout and planning of the major regions of MAA). Comparatively, the traditional models are less efficient, objective, unified, and low-cost than the M-MSZ model in the application practice of village-town system planning.

Supplementary Materials: The following are available online at http://www.mdpi.com/2071-1050/11/7/1855/s1, Table S1: Evaluation table of ecosystem vulnerability.

Author Contributions: Y.Z. constructed the methodology, designed the experiments, made the data analysis and prepared the original draft; H.L. and Q.Y. directed experimental design and worked on the review and editing of the paper. P.S. worked on the structure design and editing of the paper, as well the language correction.

Funding: Foundation projects: National Natural Science Foundation of China $(41501173,51578176)$.

Acknowledgments: Thanks to all the experts for their constructive comments and helpful suggestions that led to significant improvements to this paper.

Conflicts of Interest: The authors declare no conflict of interest.

\section{References}

1. Bao, J.; Peng, Z.W. Conflict of Power and Rights and Spatial Mismatch of Rights on the Rural Homestead Approval: A Research from the Perspective of Land Development Right. Plan. Stud. 2017, 41, 35-40, 58. [CrossRef]

2. Long, H.; Li, Y.; Liu, Y.; Woods, M.; Zou, J. Accelerated Restructuring in Rural China Fueled by 'increasing Vs. Decreasing Balance' Land-Use Policy for Dealing with Hollowed Villages. Land Use Policy 2012, 29, 11-22. [CrossRef]

3. Ma, B.R.; Tian, G.J.; Kong, L.Q.; Liu, X.J. How China's Linked Urban-Rural Construction Land Policy Impacts Rural Landscape Patterns: A Simulation Study in Tianjin, China. Landsc. Ecol. 2018, 33, 1417-1434. [CrossRef]

4. Long, H.; Heilig, G.K.; Li, X. Socio-Economic Development and Land-Use Change: Analysis of Rural Housing Land Transition in the Transect of the Yangtse River, China. Land Use Policy 2007, 24, 141-153. [CrossRef]

5. Chinigò, D. Rural Radicalism and the Historical Land Conflict in the Malawian Tea Economy. J. South. Afr. Stud. 2016, 42, 283-297. [CrossRef]

6. García-Ayllón, S. Rapid development as a factor of imbalance in urban growth of cities in Latin America: A perspective based on territorial indicators. Habitat Int. 2016, 58, 127-142. [CrossRef] 
7. Saleh, A. Concept of Village Regrouping as an Alternative Strategy for Sustainable Micro Regional Development. In Proceedings of the Conference on Urban Zoning and Architectural Design for Sustainable Development (UPADSD), Lecce, Italy, 14-16 October 2015. [CrossRef]

8. Owusu-Ansah, J.; Braimah, I. The dual land management systems as an influence on physical development outcomes around Kumasi, Ghana. J. Hous. Built Environ. 2013, 28, 689-703. [CrossRef]

9. Hui, E.C.M.; Wu, Y.; Deng, L.; Zheng, B. Analysis on Coupling Relationship of Urban Scale and Intensive Use of Land in China. Cities 2015, 42, 63-69. [CrossRef]

10. Zhong, T.; Qian, Z.; Huang, X.; Zhao, Y.; Zhou, Y.; Zhao, Z. Impact of the Top-Down Quota-Oriented Farmland Preservation Planning on the Change of Urban Land-Use Intensity in China. Habitat Int. 2018, 77, 71-79. [CrossRef]

11. Orea, L.; Perez, J.A.; Roibas, D. Evaluating the Double Effect of Land Fragmentation on Technology Choice and Dairy Farm Productivity: A Latent Class Model Approach. Land Use Policy 2015, 45, 189-198. [CrossRef]

12. Xia, N.K.; Wang, D.X. An Analysis on the Reform of Rural Land Circulation and Urban-Rural Planning. Urban Plan. Forum 2009, 82-88. [CrossRef]

13. Short, A.G. Governing Change: Land-Use Change and the Prevention of Nonpoint Source Pollution in the North Coastal Basin of California. Environ. Manag. 2013, 51, 108-125. [CrossRef] [PubMed]

14. Tilt, B. The Politics of Industrial Pollution in Rural China. J. Peasant Stud. 2013, 40, 1147-1164. [CrossRef]

15. Godwin, I.; Ndukaku, O.; Emmanuel, I. Traditional Ruler, Environmental Education, Pollution and Rural Communities in Nigeria: Challenges and Prospects. Eur. J. Sustain. Dev. 2016, 5, 75-85. [CrossRef]

16. Mahanty, S.; Dang, T. Between 'State' and 'Society': Commune Authorities and the Environment in Vietnam's Craft Villages. Asia Pac. Viewp. 2015, 56, 267-281. [CrossRef]

17. Gao, W.J.; Lian, Z.Q. The Planning of Village System. Small Town Plan. 2000, 24, 30-32. [CrossRef]

18. Martinez, B.E. Adaptive Strategies: Migration and Labor Mobility in the Context of Globalization in Mexico. Rev. San Gregor. 2017, 18, 100-113.

19. Yenigul, S.B. New Approaches in Rural Development Policies and the Effects of These Approaches on Turkey's Rural Development Policies. Planlama-Plan. 2017, 27, 16-25. [CrossRef]

20. Van, V.J.; De Groot, H.L.F.; Rietveld, P.; Verburg, P. Manifestations and Underlying Drivers of Agricultural Land Use Change in Europe. Landsc. Urban Plan. 2015, 133, 24-36. [CrossRef]

21. Huang, Z.; Wei, Y.D.; He, C.; Li, H. Urban Land Expansion Under Economic Transition in China: A Multi-Level Modeling Analysis. Habitat Int. 2015, 47, 69-82. [CrossRef]

22. Wang, Y.F.; Liu, Y.S.; Li, T.T. The Spatio-Temporal Patterns of Urban-Rural Development Transformation in China Since 1990. Habitat Int. 2016, 53, 178-187. [CrossRef]

23. Shi, Y.S. A Summary of the Research on Village and Town System at Home and Abroad. Urban Plan. Int. 2007, 84-88. [CrossRef]

24. Makki, M.S. Regional and Urban Population Size Weights in Saudi Arabia, 1962-1974. Geojournal 1986, 13, 111. [CrossRef] [PubMed]

25. Chemisov, B.H.; Khusaynov, D.Y. A Mathematical Model of Hierarchical Structure of Rural Settlements Region. Sci. Bull. Polissia 2015, 2, 32-38.

26. Lee, H.W. The Change of Rank-Size Distribution Under the Economic Development in Korea: 1995-2015. Korean Urban Geogr. Soc. 2017, 20, 45-57. [CrossRef]

27. Mengue, A.; Khodja, A.; Gilg, J.P. Novel Approach to a Demographic Survey in Rural Africa by Remote Sensing: Adjustment of Official Census Data Using a Distribution Function. Int. J. Remote Sens. 1998, 19, 2705-2719. [CrossRef]

28. Vollet, D. Estimating the Direct and Indirect Impact of Residential and Recreational Functions on Rural Areas: An Application to Five Small Areas of France. Eur. Rev. Agric. Econ. 1998, 25, 528-549. [CrossRef]

29. Dou, Y.; Luo, X.; Dong, L.; Wu, C.; Liang, H.; Ren, J. An Empirical Study on Transit-Oriented Low-Carbon Urban Land Use Planning: Exploratory Spatial Data Analysis (ESDA) on Shanghai, China. Habitat Int. 2016, 53, 379-389. [CrossRef]

30. Chang, N. A Grey Fuzzy Multiobjective Programming Approach for the Optimal Planning of a Reservoir Watershed. Part A: Theoretical Development. Water Res. 1996, 30, 2329-2334. [CrossRef]

31. Liu, Y.; Lu, S.; Chen, Y. Spatio-Temporal Change of Urban-Rural Equalized Development Patterns in China and Its Driving Factors. J. Rural Stud. 2013, 32, 320-330. [CrossRef] 
32. Feng, S.; Xu, L.D. Hybrid Artificial Intelligence Approach to Urban Planning. Expert Syst. 2010, 16, $248-261$. [CrossRef]

33. Turner, B.L.; Wuellner, M.; Nichols, T.; Gates, R.N.; Tedeschi, L.; Dunn, B.H. Development and Evaluation of a System Dynamics Model for Investigating Agriculturally Driven Land Transformation in the North Central United States. Nat. Resour. Model. 2016, 29, 179-228. [CrossRef]

34. Kluge, K.C.; Morgenthaler, M.K. Multihorizon Reactive and Deliberative Path Planning for Autonomous Cross-Country Navigation. Proceedings of SPIE. Int. Soc. Opt. Eng. 2004, 461-472. [CrossRef]

35. Liu, Y.L.; Kong, X.S.; Liu, Y.F.; Chen, Y. Simulating the Conversion of Rural Settlements to Town Land Based on Multi-Agent Systems and Cellular Automata. PLoS ONE 2013, 8, e79300. [CrossRef] [PubMed]

36. Zhang, L.; Wei, Y.H.; Meng, R. Spatiotemporal Dynamics and Spatial Determinants of Urban Growth in Suzhou, China. Sustainability 2017, 9, 393. [CrossRef]

37. Wu, F.L. Calibration of Stochastic Cellular Automata: The Application to Rural-Urban Land Conversions. Int. J. Geogr. Inf. Sci. 2002, 16, 795-818. [CrossRef]

38. Long, Y.; Shen, Z.J. Scenario Analysis of Beijing Urban form Based on Constrained CA Method. Acta Geogr. Sin. 2010, 65, 643-655. [CrossRef]

39. Chuai, X.; Huang, X.; Wang, W.; Wu, C.; Zhao, R. Spatial Simulation of Land Use Based on Terrestrial Ecosystem Carbon Storage in Coastal Jiangsu, China. Sci. Rep. 2014, 4. [CrossRef] [PubMed]

40. Wu, M.; Ren, X.Y.; Che, Y.; Yang, K. A Coupled SD and CLUE-S Model for Exploring the Impact of Land Use Change on Ecosystem Service Value: A Case Study in Baoshan District, Shanghai, China. Environ. Manag. 2015, 56, 402-419. [CrossRef] [PubMed]

41. Rienow, A.; Goetzke, R. Supporting SLEUTH-Enhancing a Cellular Automaton with Support Vector Machines for Urban Growth Modeling. Comput. Environ. Urban Syst. 2015, 49, 66-81. [CrossRef]

42. Xi, F.; He, H.S.; Clarke, K.C.; Hu, Y.; Wu, X.; Liu, M.; Shi, T.; Geng, Y.; Gao, C. The Potential Impacts of Sprawl on Farmland in Northeast China-Evaluating a New Strategy for Rural Development. Landsc. Urban Plan. 2012, 104, 34-46. [CrossRef]

43. Kamusoko, C.; Aniya, M.; Adi, B.; Manjoro, M. Rural Sustainability Under Threat in Zimbabwe-Simulation of Future Land Use/Cover Changes in the Bindura District Based on the Markov-Cellular Automata Model. Appl. Geogr. 2009, 29, 435-447. [CrossRef]

44. Chakraborti, S.; Das, D.N.; Mondal, B. A Neural Network and Landscape Metrics to Propose a Flexible Urban Growth Boundary: A Case Study. Ecol. Indic. 2018, 93, 952-965. [CrossRef]

45. Fan, J.; Sun, W.; Yang, Z.S.; Fan, P.; Chen, D. Focusing on the Major Function-Oriented Zone: A New Spatial Planning Approach and Practice in China and Its 12th Five-Year Plan. Asia Pac. Viewp. 2012, 53, 86-96. [CrossRef]

46. Wu, Y.; Peng, Y.; Zhang, X.; Skitmore, M.; Song, Y. Development Priority Zoning (DPZ)-Led Scenario Simulation for Regional Land Use Change: The Case of Suichang County, China. Habitat Int. 2012, 36, 268-277. [CrossRef]

47. Peng, J.; Ma, J.; Yuan, Y.; Wei, H.; Pang, W. Integrated Urban Land-Use Zoning and Associated Spatial Development: Case Study in Shenzhen, China. J. Urban Plann. Dev. 2015, 141, 05014025. [CrossRef]

48. Fan, J.; Li, X.P. The Scientific Foundation of China's Main Function Regionalization. J. Geogr. Sci. 2009, 19, 5-21. [CrossRef]

49. Chen, S.Z.; Zhou, Z.F.; Wang, P. A New Methodology to Quantitatively Define Major Function Oriented Zones of County: The Case of Libo County. In Proceedings of the 2016 International Conference on Environment, Climate Change and Sustainable Development (ECCSD 2016), Beijing, China, 28-29 May 2016; pp. 287-291.

50. Fan, J.; Sun, W.; Zhou, K.; Chen, D. Major Function Oriented Zone: New Method of Spatial Regulation for Reshaping Regional Development Pattern in China. Chin. Geogr. Sci. 2012, 22, 196-209. [CrossRef]

51. Yasi, T.; Xuesong, K.; Yaolin, L. Combining Weighted Daily Life Circles and Land Suitability for Rural Settlement Reconstruction. Habitat Int. 2018, 76, 1-9. [CrossRef]

52. Zhu, C.B.; Deng, Y.D. Basic Methods on Regional Orientation. City Plan. Rev. 2000, 32-35. [CrossRef]

53. Christiane, W. Interaction Model Application for Urban Planning. Urban Plan. Int. 2006, 21, 77-82. [CrossRef]

54. Abedini, A.; Ebrahimkhani, H.; Abedini, B. Mixed Method Approach to Delineation of Functional Urban Regions: Shiraz Metropolitan Region. Urban Plan. Dev. 2016, 142, 23-29. [CrossRef] 
55. Jacques, L. A Model of Urbanization with Nonlinear Migration Flows. Int. Reg. Sci. Rev. 1986, 10, $221-242$. [CrossRef]

56. Batty, M. A Strategy for Generating and Testing Models of Migration and Urban-Growth. Reg. Stud. 1983, 17, 223-236. [CrossRef] [PubMed]

57. Rem, G.P.; Liu, L.M.; Sun, J.; Zhuo, D.; Yuan, C. Using the "Cell-Chain-Shape" Method to Identify and Classify Spatial Development Patterns of Administrative Villages in the Metropolitan Suburbs. Acta Geogr. Sin. 2017, 72, 2147-2165. [CrossRef]

58. Xiong, H.; Zheng, B.; Jia, L. Research on the Integration of Towns Based on Industrial Coordinated Development-Taking Changsha Area as an Example. Econ. Geogr. 2017, 37, 124-131. [CrossRef]

59. Kong, X.S.; Jin, L.L.; Qie, Y.; Zhang, Y.; Xu, Y. Layout Optimization of Rural Settlements Based on Point-Axis Theory. Trans. Chin. Soc. Agric. Eng. (Trans. CSAE) 2014, 30, 192-200. [CrossRef]

60. Gong, J.; Liu, Y.; Chen, W. Land Suitability Evaluation for Development Using a Matter-Element Model: A Case Study in Zengcheng, Guangzhou, China. Land Use Policy 2012, 29, 464-472. [CrossRef]

61. Cengiz, T.; Akbulak, C. Application of Analytical Hierarchy Process and Geographic Information Systems in Land-Use Suitability Evaluation: A Case Study of DÜMrek Village (Canakkale, Turkey). Int. J. Sustain. Dev. World Ecol. 2009, 16, 286-294. [CrossRef]

62. Liu, Y.; Cui, J.; Kong, X.; Chen, Z. Assessing Suitability of Rural Settlements Using An Improved Technique for Order Preference by Similarity to Ideal Solution. Chin. Geogr. Sci. 2016, 26, 638-655. [CrossRef]

63. Liu, Y.; Ye, Q.; Li, J.; Kong, X.; Jiao, L. Suitability Evaluation of Rural Settlements Based on Accessibility of Production and Living: A Case Study of Tingzu Town in Hubei Province of China. Chin. Geogr. Sci. 2016, 26, 550-565. [CrossRef]

64. Jiang, R.; Qiu, J. Exploration and Reflections on Village-Town Planning of Chengdu in the Context of Urban-Rural Integration. City Plan. Rev. 2012, 36, 86-91.

65. Zhao, Y.J.; Leng, H.; Sun, P.J.; et al. A Spatial Zoning Model of Municipal Administrative Areas Based on Major Function-Oriented Zones. Sustainability 2018, 10, 2976. [CrossRef]

66. Mazzocchi, C.; Corsi, S.; Sali, G. Agricultural Land Consumption in Periurban Areas: A Methodological Approach for Risk Assessment Using Artificial Neural Networks and Spatial Correlation in Northern Italy. Appl. Spat. Anal. Policy 2017, 10, 3-20. [CrossRef]

67. Kamali, F.P.; Borges, J.A.R.; Meuwissen, M.; et al. Sustainability Assessment of Agricultural Systems: The Validity of Expert Opinion and Robustness of a Multi-Criteria Analysis. Agric. Syst. 2017, 157, 118-128. [CrossRef]

68. Evett, R.R.; Cuthrell, R.Q. A conceptual framework for a computer-assisted, morphometric-based phytolith analysis andclassification system. J. Archaeol. Sci. 2016, 68, 70-78. [CrossRef]

69. Zhao, X.; Huang, Q.X.; He, C.Y. Scenarios Simulation of the Spatial Stress on Wetlands by Urban Expansion: A Case Study of Huailai County. J. Nat. Resour. 2017, 9, 108-115. [CrossRef]

70. Xia, C.; Wang, H.J.; Zhang, A.Q. Multi-Scenario Simulation and Policy Analysis of Urban Space Under the Effects of Coupling and Control Ling. Hum. Geogr. 2017, 32, 67-76. [CrossRef]

71. Zhang, T.; Wang, Y.L.; Liu, Y.X.; Peng, J. Multi-Temporal Detection of Landscape Evolution in Western Shenzhen City During 1987-2015. Acta Geogr. Sin. 2016, 71, 2170-2184. [CrossRef]

72. Wu, Y.Z.; You, H.Y.; Chen, Q.H. Study on Strategic Planning Technique Based on Multi-Dimensional Gis-Scenario Analysis. City Plan. Rev. 2014, 38, 35-43. [CrossRef]

73. Arsanjani, J.J.; Helbich, M.; Kainz, W.; Boloorani, A.D. Integration of Logistic Regression, Markov Chain and Cellular Automata Models to Simulate Urban Expansion. Int. J. Appl. Earth Obs. Geoinform. 2013, 21, 265-275. [CrossRef]

74. Long, H.; Zou, J.; Pykett, J.; Li, Y.R. Analysis of Rural Transformation Development in China Since the Turn of the New Millennium. Appl. Geogr. 2011, 31, 1094-1105. [CrossRef]

75. Marwa, W.A.; Halmy, P.E.; Gessler, J.A.; Hicke BB, S. Land Use/Land Cover Change Detection and Prediction in the North-Western Coastal Desert of Egypt Using Markov-CA. Appl. Geogr. 2015, 63, 101-112. [CrossRef]

76. Gashaw, T.; Tulu, T.; Argaw, M.; Abeyou, W.W.; Terefe, T.; Mengistie, K. Estimating the Impacts of Land Use/Land Cover Changes on Ecosystem Service Values: The Case of the Andassa Watershed in the Upper Blue Nile Basin of Ethiopia. Ecosyst. Serv. 2018, 31, 219-228. [CrossRef]

77. Bryan, B.A.; Ye, Y.Q.; Zhang, J.E. Land-Use Change Impacts on Ecosystem Services Value: Incorporating the Scarcity Effects of Supply and Demand Dynamics. Ecosyst. Serv. 2018, 32, 144-157. [CrossRef] 
78. Du, Q.Y.; Wang, L.; Ren, F.; Zhao, Z.Y. Measuring and Analysis of Urban Competitiveness of Chinese Provincial Capitals in 2010 Under the Constraints of Major Function-Oriented Zoning Utilizing Spatial Analysis. Sustainability 2014, 6, 3374-3399. [CrossRef]

79. Liu, W.; Liu, J.; Kuang, W.; Ning, J. Examining the Influence of the Implementation of Major Function-Oriented Zones on Built-Up Area Expansion in China. J. Geogr. Sci. 2017, 27, 643-660. [CrossRef]

80. Ren, G.P. The Evolution and Development Model of Rural Landscape Under the Background of Rapid Urbanization. Ph.D. Thesis, China Agricultural University, Beijing, China, 2018.

81. Zhu, L.; Xiao, L.S.; Guo, Q.H. Research on coupling pattern between urbanization and industrial structure: A case study in rapid urbanizing Xia-Zhang-Quan area. China Popul. Resour. Environ 2017, 25, 98-102. [CrossRef]

82. Sun, J.W.; Luo, J.; Kong, X.S. Zoning and Potential Calculation for Rural Settlements Consolidation 1n Qinba Mountainous Area Based on Spatial Characteristics. Hum. Geogr. 2017, 32, 80-87, 94. [CrossRef]

83. Sun, J.W.; Kong, X.S.; Tian, Y.S.; Luo, J. Identifying Reconstruction Directions of Rural Settlements Based on Analysis of Spatial Combination Features. Sci. Geogr. Sin. 2017, 5, 111-118. [CrossRef]

84. Zolekar, R.B.; Bhagat, V.S. Multi-Criteria Land Suitability Analysis for Agriculture in Hilly Zone: Remote Sensing and GIS Approach. Comput. Electron. Agric. 2015, 118, 300-321. [CrossRef]

85. Ayla, B.; Yavuz, F.; Asli, S.G. AHP and GIS Based Land Suitability Analysis for Cihanbeyli (Turkey) County. Environ. Earth Sci. 2016, 75, 813. [CrossRef]

86. Yalew, S.G.; van Griensven, A.; Mul, M.L.; van der Zaag, P. Land Suitability Analysis for Agriculture in the Abbay Basin Using Remote Sensing, GIS and AHP Techniques. Model. Earth Syst. Environ. 2016, 2, 101. [CrossRef]

87. Huang, Q.; Liu, Y.; Li, M.; Mao, K.; Li, F.X.; Chen, Z.J.; Chen, C.; Hu, W. Thematic Maps for County-Level Land Use Planning in Contemporary China. J. Maps 2012, 8, 185-188. [CrossRef]

88. Song, J.T.; Gu, C.L. Theory and Method of Urban System Planning. Acta Geogr. Sin. 1988, 2, 97-107. [CrossRef]

89. Available online: https://baike.baidu.com/item/\%E5\%9F\%8E\%E9\%95\%87\%E4\%BD $\% 93 \% E 7 \% B 3 \% B B \%$ E8\%A7\%84\%E5\%88\%92/7788425?fr=Aladdin (accessed on 13 December 2014).

90. Available online: https://baike.baidu.com/item/\%E6\%9D\%91\%E9\%95\%87\%E8\%A7\%84\%E5\%88\%92/ 1918708?fr=Aladdin (accessed on 13 January 2016). 